\title{
HIGH LEVEL WASTE CANISTER THERMAL CHARACTERIZATION FOR THE SEALED STORAGE CASK CONCEPT
}

D. E. Larson

Waste Management Special Studies Development Engineering Department Research and Engineering

MOTICE

This report was prepared as an account of work sponsored by the United States Government. Neither the United States nor the United States Energy Research and Development Administration, nor any of their enployees, nor any of their contractors, subcontractors, or their employees, makes any warranty, express or implied, or assumes any legal liability or responsibility for the accuracy, completeness or usefulness of any information, apparatus, product or process disclosed, or represents that its use would not infringe privately owned rights.

Prepared for the Atomic Energy Commission by Atlantic Richfield Hanford Company under Contract AT (45-1)-2130 


\section{DISCLAIMER}

This report was prepared as an account of work sponsored by an agency of the United States Government. Neither the United States Government nor any agency Thereof, nor any of their employees, makes any warranty, express or implied, or assumes any legal liability or responsibility for the accuracy, completeness, or usefulness of any information, apparatus, product, or process disclosed, or represents that its use would not infringe privately owned rights. Reference herein to any specific commercial product, process, or service by trade name, trademark, manufacturer, or otherwise does not necessarily constitute or imply its endorsement, recommendation, or favoring by the United States Government or any agency thereof. The views and opinions of authors expressed herein do not necessarily state or reflect those of the United States Government or any agency thereof. 


\section{DISCLAIMER}

Portions of this document may be illegible in electronic image products. Images are produced from the best available original document. 
TABLE OF CONTENTS

Page

INTRODUCTION . . . . . . . . . . . . . . . . 1 SUMMARY . . . . . . . . . . . . . . . . . . 2

CANISTER AND STORAGE UNIT DESIGN. . • • . . . . . . . 5 BASES. •. . . . . . . . . . . . . . . 5 STORAGE UNIT CHARACTERISTICS . . . . . . . . . 6 HEAT TRANSFER 。. . . . . . . . . . . . . 8 RADIATION SHIELDING ................... 10 ACKNOWLEDGMENTS . . . . . . . . . . . . . . . . 13

\section{LIST OF TABLES}

Title

Page

TABLE 1 - SEALED STORAGE CASK CONCEPT GENERIC STORAGE UNIT HEAT TRANSFER CHARACTERIZATION . • • • • 14

TABLE 2 - COMMERCIAI NUCLEAR FUELS REFERENCE EXPOSURE CONDITIONS . . . . . . . . . . . . 16

TABLE 3 - NORMAL OPERATING TEMPERATURES FOR MULTIPLE BARRIER STORAGE UNIT CONTAINING OPTIMUM REFERENCE CANISTER. . . . . . . . . . . 17

TABLE 4 - AIR FLOW BLOCKAGE TEMPERATURES FOR MULTIPLE BARRIER STORAGE UNIT CONTAINING OPTIMUM REFERENCE CANISTER . . . . . . . . . . . . . 18

TABLE 5 - BURIAI TEMPERATURES AT ONE MONTH FROM MULTIPLE BARRIER STORAGE UNIT CONTAINING OPTIMUM REFERENCE CANISTER . . . . . . . . . . . . 19

TABLE 6 - NORMAL OPERATING TEMPERATURES FOR MULTIPLE BARRIER STORAGE UNIT CONTAINING OPTIMUM MAXIMUM CANISTER SIZE . . . . . . . . . . . 20 
Title

Page

TABLE 7 - AIR FLOW BLOCKAGE TEMPERATURES

FOR MULTIPLE BARRIER STORAGE UNIT CONTAINING

OPTIMUM MAXIMUM CANISTER SIZE . . . . . . . . . . . 21

TABLE 8 - BURIAL TEMPERATURES AT ONE MONTH

FROM MULTIPLE BARRIER STORAGE UNIT CONTAINING

OPTIMUM MAXIMUM CANISTER SIZE . . . . . . . . . . 22

LIST OF FIGURES

Title

$\underline{\text { Page }}$

FIGURE 1 - SEALED STORAGE CASK CONCEPT

GENERIC WASTE STORAGE UNIT NORMAL OPERATION • • • • . . 23

FIGURE 2 - HIGH LEVEL WASTE HEAT

GENERATION FOR REFERENCE FUELS. . . . . . . . . . . . . 24

FIGURE 3 - MULTIPLE OVERPACR CONFIGURATION. • • • • . 25

FIGURE 4 - CONCRETE SHILEDING REQUIRED

TO REDUCE CANISTER AND CASK GAMMA DOSE

RATE TO ONE MILLIREM PER HOUR . . . . . . . . . . . . . 26

FIGURE 5 - CONCRETE SHIELDING REQUIRED

TO REDUCE CANISTER AND CASK NEUTRON DOSE

RATE TO ONE MILIIREM PER HOUR . . . . . . . . . . . 27

FIGURE 6 - SEALED STORAGE CASK CONCEPT

STORAGE UNIT WEIGHT FOR VARIABLE

CANISTER DIMENSIONS .................. . 28

APPENDICES

APPENDIX A. . . . . . . . . . . . . . . . 29

APPENDIX B. . . . . . . . . . . . . . . . 36 


\section{INTRODUCTION}

High level waste, generated by the chemical reprocessing of commercial nuclear reactor fuels, will be converted to a stable solid, packaged in a high integrity metal container (canister), and transferred to a Federal repository for storage. The waste and canister properties pertinent to storage require definition to assure that the filled canister will be compatible with the storage concept. The purpose of this study is to characterize the waste storage unit thermal behavior for normal and accident situations so that safe acceptance limits on heat content can be established for canisters received at the Retrievable surface storage Facility. The storage method used for the analyses is the sealed Storage Cask concept. Storage unit radiation shielding requirements for various waste and canister characteristics are also reviewed. 
SUMMARY

A study was performed to determine the compatibility of various high level commercial radioactive waste and canister characteristics with the Sealed storage Cask Concept (SSCC) for the Retrievable Surface Storage Facility (RSSF). The parameters included were waste form (calcine and glass), heat generation rate $(0.25-5$ kilowatts per hour per cubic foot). radiation generation rate (0-10 year old reference waste), and canister diameter (6-24 inches) and length (10-15 feet). The canister was assumed to be a right circular cylinder with sufficient internal finning to maintain the waste centerline temperature below the maximum stable waste temperature under normal operating conditions. The storage unit components were a simplified generic design of a reference case. The situations studied for conceptual compatibility were storage unit temperature limits for normal operations and air flow blockage in the unit. Unit burial cases were also examined. shielding requirements and storage unit weights were determined for the various filled canisters.

Material properties at elevated temperatures are limiting conditions for concept compatibility. As the waste specific heat generation rate or canister diameter increases, storage unit temperatures increase significantly. The storage cask temperature of $1200^{\circ} \mathrm{F}$; encountered in the air flow stoppage situation; is the limiting credible heat transfer accident condition for determining filled canister acceptability. Under limiting cask temperature conditions the concrete temperature is above $900^{\circ} \mathrm{F}$, where significant spalling will occur. This is acceptable under accident conditions as long as the cask integrity is not impaired. Almost any size canister is conceptually compatible with the SSCC providing the 
specific heat of the waste is low enough. Storage unit temperatures for the situations studied do not increase substantially as the canister length is increased from 10 to 15 feet.

An optimum canister for the reference waste, from Pressurized Water Reactor-Uranium (PWR-U) fuel exposed to 33,000 megawatt days per metric ton at 2 cubic feet per metric ton and 10 years old, has an 18.5 inch internal diameter and is 15 feet 1ong. This represents $15.4 \mathrm{kilowatts}$ of heat in a 28 cubic foot volume. Another optimum would be the maximum heat which can be placed in a reference canister, 10 feet $10 n g$ and 12 inches internal diameter. The maximum amount of heat is 10.1 kilowatts in this case. Results show that these canisters can be safely overpacked in up to three additional overpacks and casks and still be safely stored. The economic optimum canister may be determined after additional studies are performed to find minimum storage unit material requirements, establish canister acceptance costs, and account for fuel reprocessor costs for high level waste handling, storage and transportation.

Cask shield design is somewhat insensitive to canister and waste characteristics except for Pressurized Water ReactorPlutonium (PWR-PU) fuel derived waste. Minimal shield thickness required for all waste, cask and canister combinations, varies between 34 and 44 inches for non-PWR-Pu derived waste. The associated storage unit weights may vary significantly between about 53 and 160 tons. The PWR-Pu derived waste could require up to 20 inches additional concrete shielding to adequately attenuate the neutrons. The most significant neutron shielding parameter is the effect of waste fuel type (PWR-Pu versus other) and exposure history followed by waste 
form and canister diameter. The storage unit for the reference waste in the 18.5 inch diameter and 15 feet long optimum canister requires 40 inches of concrete shielding, which includes a modest contingency and results in a total unit weight of 120 tons. 
CANISTER AND STORAGE UNIT DESIGN

\section{BASES}

For a waste filled canister to be compatible with the sealed storage cask concept, it and the storage cask shall be able to maintain their integrity under all credible conditions. The concrete radiation shield is required to maintain its integrity, no gross cracks or spalling, only under normal operating conditions and to protect cask integrity under all credible conditions. The conditions considered for the heat transfer analyses are defined as follows:

- Normal Operating Conditions

A single storage unit is placed outdoors in $80^{\circ} \mathrm{F}$ air with zero wind velocity. Solar heating is neglected.

- Air Coolant Flow Blockage (steady state)

The air inlet and outlet ports are plugged with concrete of the same thickness and properties as the concrete radiation shield. Other conditions are the same as the "Normal Storage Operation."

Solar heating effects are neglected on the following bases. The radiation shield thermal capacity is large, and the day time heating and night time heat loss sufficiently average each other such that the net thermal effects on the unit interior is small.

The condition of storage unit burial is included in the analyses, although this situation is not considered of sufficient probability as to deem credible. This case consists of a storage unit buried in the earth with the top of the storage cask 5 feet below the ground surface. The concrete shield maintains its integrity and has the same thermal properties as the ground. The storage unit temperatures encountered at this depth approach those for an infinitely deep buried unit. 


\section{STORAGE UNIT CHARACTERISTICS}

A simplified generic storage unit design was used for this parametric study. The design used is shown in Figure 1, and the design and material assumptions are indicated in Table 1. The canister is 6 to 24 inches in diameter and 10 and 15 feet in length. A maximum canister length of 15 feet was selected since this is about the length of Light water Reactor fuel assemblies, and experience exists for shipping and handling these assemblies in fuel reprocessor facilities and reactors. All material thicknesses and gap widths, except for the waste canister diameter and height, were held constant. Material characteristics were considered constant for computations, and average properties were used.

Solidified waste characteristics were assumed to be a hypothetical glass or calcine with variable heat generating capacity. The waste properties are indicated in Table 1. A heat generation range of $0.25-5$ kilowatts per cubic foot was selected to cover a wide range of variables such as fuel exposure, waste age, the cubic feet of waste per equivalent metric ton of fuel, and the type of fuel from which the waste was generated. For the reference fuel types and characteristics indicated in Table 2 the heat generation rates of the high level wastes for various times after fuel discharge are shown in Figure 2. The effects of different fuel exposure on waste heat generation characteristics are shown in Appendix A.

For the reference optimum cases (maximum heat in reference canister and maximum canister size for reference waste which is discussed later) heat transfer calculations were also performed. Additional calculations for these cases include the following multiple overpack configurations. 


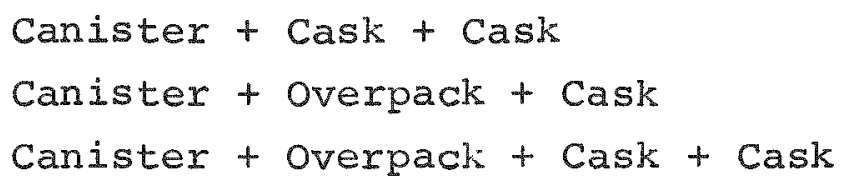

The overpack possesses the same material properties and thickness as the canister. The additional cask has the same material characteristics and thickness as the first cask. Gaps between all metal containers are maintained at 1.5 inches. The spacings between the outer metal container and the concrete shield are 6 inches. The multiple overpack configurations are shown in Figure 3 . 


\section{HEAT TRANSFER}

Detailed results of the heat transfer analyses for the generic storage units are contained in Appendix B. These studies indicate that the size and heat generation limitations imposed on a filled canister, which may be received at the RSSF, are determined by a cask temperature limit of $1200^{\circ} \mathrm{F}$ encountered in the air flow stoppage cases. Also, there is no major increase in storage unit temperatures whether the canister is 10 or 15 feet long for acceptable, equivalent specific waste heat generation and canister diameter. For instance, the maximum temperature differences of similar storage unit components is less than about $50^{\circ} \mathrm{F}$ for normal operating conditions and $100^{\circ} \mathrm{F}$ for an accident situation. Thus significantly more waste, up to 50 percent, could be stored in a 15 foot canister rather than a 10 foot one.

More waste heat can be stored in a larger diameter canister, although the specific heat generation rate will have to be reduced. In a 10 foot long canister, 11.7 kilowatts can be stored in an 18 inch diameter canister whereas about $10 \mathrm{kilo-}$ watts of heat can be placed in a 12 inch diameter canister based on the no air flow condition. But, the specific heat generation rate would be 1.3 versus 0.65 kilowatts per cubic foot for the 12 and 18 inch diameter cases respectively. Two reference optimum cases were established with regard to waste heat storage. These were the maximum heat generation rates that could be placed in a reference canister and the largest canister volume that can be filled with reference waste. The reference canister is 10 feet long and 12 inches internal diameter. The reference waste is 2 cubic feet per metric ton and comes from PWR-U fuel which was exposed to 33,000 megawatt days per metric ton and is 10 years old. The 
maximum allowable heat generation which can be placed in a filled reference canister is 10.1 kilowatts, and the maximum size canister that can be filled with reference waste is 15 feet long and 18.5 inches internal aiameter, which will hold 15.4 kilowatts of heat.

Additional calculations were performed for the reference optimum cases to determine the effects of overpacking these canisters. The normal operation, air flow stoppage, and burial calculations were performed for the optimum cases for the following multiple overpack arrangements.

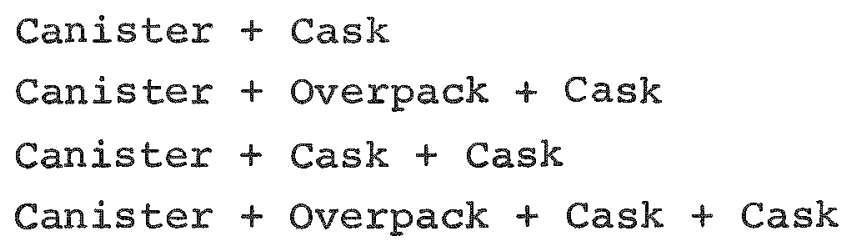

These multiple overpack situations would occur where there has been failure of one or more storage unit waste barriers. The results of these calculations are summarized in Tables 3 through 8 for the optimum reference canister and reference waste cases respectively. These computations show that if the canister is overpacked the outer barrier is within acceptable temperature limitations, and the inner barrier temperatures do not increase significantly. This is due to the efficient heat transfer by radiation at the temperatures experienced and the increased heat transfer area of the outer overpacks and shield. 
RADIATION SHIELDING

An additional consideration for receiving filled waste canisters at the RSSF is the shielding necessary for the facility and storage unit to assure the safety of operating personnel. Shielding requirements will have a significant impact on facility and storage unit costs but little effect on normal storage unit operating temperatures. Shielding thickness significantly affects heat removal from the storage unit only in the air flow stoppage cases where the heat must be conducted through the shield. Temperature changes for shield thicknesses modestly deviating from 40 inches would probably not be significant.

Shield thicknesses required to reduce the gamma and neutron dose rates to 1 millirem per hour for a storage unit with variable canister dimensions, waste types, and waste characteristics are shown in the figures indicated below.

$$
\text { Situation }
$$

Figure Number

Garnma Radiation: Calcine and Glass Waste

Canister Diameters, inches: 6-24 4

Neutron Radiation: Calcine and Glass Waste

Canister Diameters, inches: 6-24 5

The concrete used for the reference shield is ordinary concrete containing 2 weight percent water. The water content is conservatively low which may be representative of concrete encountering a high temperature environment.

The gamma shielding data indicate that shield thickness varies moderately with waste and canister characteristics. The inclusion of the 2 inch steel cask between the canister and 
the shield reduces the concrete shield requirements by about 6 inches. Over the entire spectrum of waste and canister characteristics, the concrete thickness requirement varies over about a 10 inch thickness range for a storage unit. The neutron shielding data indicates that the concrete shield thickness requirements vary significantly due to waste properties and canister design. Neutron shielding needs for the waste from PWR-Pu fuels are about 20 inches more concrete than for other fuels due to the high neutron generating curium-244 content. The overall shield thickness increase, over that required for gamma radiation shielding, may be up to 20 inches. The presence of the cask reduces the neutron dose rate from the canister by a factor of two or represents about 3 to 4 inches of dehydrated concrete.

The primary use of the shielding data is to determine the thickness of the concrete shield. If the shield exterior is designed for a dose rate other than 1 millirem per hour, the appropriate shield thickness can be determined from the shielding figures. It requires roughly 3.5 and 1.5 inches of reference concrete to reduce the shield exterior dose rate by a factor of two for neutron and gamma radiation, respectively. Also, excess concrete should be provided in the initial storage units to allow for some uncertainties in the shielding calculations.

The weight of the storage unit as a function of canister height and diameter, and shield thickness is shown in Figure 6 . Greater than 94 percent of the storage unit weight is the shield weight, excluding the base. The storage unit weight increases significantly with increases in canister length and 
diameter, and shield thickness. The weight is primarily a design and handling problem and not a concept consideration, but at some weight there is an upper practical limit which has not yet been established. 


\section{ACKNOWLEDGMENTS}

Appreciation is expressed to H. C. Burkholder of Battelle Northwest Laboratory and A.R.F. Hawkins of Atlantic Richfield Hanford Company who performed basis heat transfer calculations. Acknowledgment is given to M. G. Zimmerman of Battelle Northwest Laboratory who provided radiation shielding and nuclear fuel exposure data. Also the efforts of R. I. Martell and B. C. Travis are appreciated for document graphics and secretarial assistance, respectively. 


\section{SEALED STORAGE CASK CONCEPT \\ GENERIC STORAGE UNIT}

HEAT TRANSFER CHARACTERIZATION

WASTE

Heat Generation Per Unit Volume $=0.25-5 \mathrm{kw} / \mathrm{ft}^{3}(0.25,0.5,1,2,5)$

Thermal Conductivity, Btu/hr-ft- ${ }^{\circ} \mathrm{F}$

Heat Capacity, Btu/1b- ${ }^{\circ} \mathrm{F}$

Density, $I \mathrm{~b} / \mathrm{ft}^{3}$

Maximum Stable Temperature, ${ }^{\circ} \mathrm{F}$

Calcine
0.2
0.2
81
1500

Glass

0.7

0.2

CANISTER

Shell: Material of Construction: 304-L stainless steel

Internal Diameter: $0.5-2$ ft $(0.5,1.0,1.5,2.0)$

Internal Height: $10-15$ ft $(10,15)$

Thickness: 0.375 in.

Thermal Conductivity: $10 \mathrm{Btu} / \mathrm{hr}-\mathrm{ft}-{ }^{\circ} \mathrm{F}$

Emissivity: 0.45

Heat Capacity: $0.12 \mathrm{Btu} / 1 \mathrm{~b}-{ }^{\circ} \mathrm{F}$

Density: $500 \mathrm{lb} / \mathrm{ft}^{3}$

Fins: Material of Construction: Carbon steel Length: Full

Penetration: $2 / 3$

Thickness: 0.25 in.

Weld: Full weld at root

Thermal Conductivity: $23 \mathrm{Btu} / \mathrm{hr}-\mathrm{ft}-{ }^{\circ} \mathrm{F}$

Heat Capacity: $0.15 \mathrm{Btu} / \mathrm{Ib}-{ }^{\circ} \mathrm{F}$

Density: $490 \mathrm{lb} / \mathrm{Et}^{3}$

Canister Fill Height: Full (neglect fin volume) 


\section{TABLE 1 (Continued)}

CASK

Material of Construction: Carbon Steel

Internal Diametar: Allow a 1.5 inch gap between cask and canister

Internal Height: Allow a 6 inch gap between cask and canister

Thickness: 2 in.

Thermal Conductivity: $26 \mathrm{Btu} / \mathrm{hr}-{ }^{\circ} \mathrm{F}-\mathrm{ft}$

Emissivity: 0.6

Heat Capacity: 0.14 Btu/Ib- ${ }^{\circ} \mathrm{F}$

Density: $490 \mathrm{lb} / \mathrm{ft}^{3}$

\section{SHIELD}

Material of Construction: Concrete

Internal Diameter: Allow a 6 inch gap between concrete and cask

Internal Height: Allow 1 foot between floor anä cask and 6 inches between cask and lid

Thickness: 40 in.

Thermal Conductivity: $0.5 \mathrm{Btu} / \mathrm{hr}-{ }^{\circ} \mathrm{F}-\mathrm{ft}$

Emissivity: 0.7

Fieat Capacity: 0.2 Btu/1b- ${ }^{\circ} \mathrm{F}$

Density: $143.51 \mathrm{~b} / \mathrm{ft}^{3}$

\section{AIR}

Ambient Temperature: $80^{\circ} \mathrm{F}$

Thermal Conductivity: $0.015 \mathrm{Btu} / \mathrm{hr}-\mathrm{ft}-{ }^{\circ} \mathrm{F}$

Heat Capacity: $0.25 \mathrm{Btu} / 1 \mathrm{~b}-{ }^{\circ} \mathrm{F}$

Density: $0.072 \mathrm{lb} / \mathrm{ft}^{2}$

\section{BURIAL EARTH}

Thermal Conductivity: $0.3 \mathrm{Btu} / \mathrm{hr}-\mathrm{ft}-{ }^{\circ} \mathrm{F}$

Soil Thermal Diffusivity: $0.0083 \mathrm{ft}^{2}-{ }^{\circ} \mathrm{F}$

Heat Capacity: $0.2 \mathrm{Btu} / \mathrm{Ib}-{ }^{\circ} \mathrm{F}$

Density: $180 \mathrm{lb} / \mathrm{ft}^{3}$ 


\section{TABIE 2}

COMMERCIAL NUCLEAR FUELS REFERENCE EXPOSURE CONDITIONS

\begin{tabular}{|c|c|c|c|c|}
\hline \multirow{2}{*}{$\begin{array}{l}\text { Exposure } \\
\text { Conditions }\end{array}$} & \multicolumn{4}{|c|}{ FUEL } \\
\hline & PWR-U & PWR-PU & GEFO & HTGR \\
\hline Burnup (MWD/MT) & 33,000 & 33,000 & 41,500 & 94,300 \\
\hline Power $(\mathrm{MW} / \mathrm{MT})$ & 30 & 30 & 48.5 & 64.6 \\
\hline Flux $\left(\mathrm{N} / \mathrm{cm}^{2}-\mathrm{sec}\right)$ & $2.9 \times 10^{13}$ & $1.5 \times 10^{13}$ & $2.7 \times 10^{15}$ & $6.5 \times 10^{13}$ \\
\hline Enrichment & & & & \\
\hline$W T g^{235} \mathrm{U}$ & 3.3 & 0.68 & 0.19 & 4.6 \\
\hline $\mathrm{WT}^{239+241} \mathrm{Pu}$ & - & 3.1 & 4.3 & - \\
\hline & - & - & - & $2.3^{233_{U}}$ \\
\hline
\end{tabular}




\section{TABLE 3}

NORMAI OPERATING TEMPERATURES FOR

MULTIPLE BARRIER STORAGE UNIT

CONTAINING OPTIMUM REFERENCE CANISTER

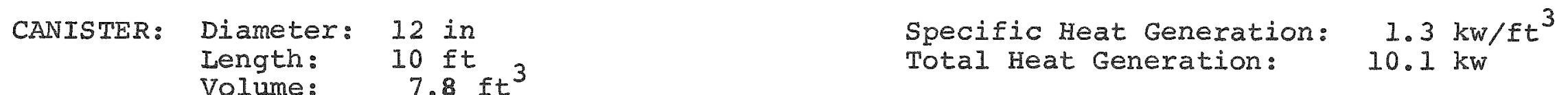

\begin{tabular}{|c|c|c|c|c|c|c|c|c|c|}
\hline \multirow[t]{3}{*}{ CONEIGURATION } & \multicolumn{9}{|c|}{ MAXIMUM COMPONENT TEMPERATURE - ${ }^{\circ} \mathrm{F}$} \\
\hline & \multirow{2}{*}{ Waste $\left.\mathbb{E}^{(\text {I }}\right)$} & \multirow[t]{2}{*}{ Canister } & \multirow[t]{2}{*}{ Overpack } & \multicolumn{2}{|c|}{ Storage Cask } & \multirow{2}{*}{$\begin{array}{l}\text { Inner } \\
\text { Shield }\end{array}$} & \multirow{2}{*}{$\begin{array}{l}\text { Outer } \\
\text { Shield }\end{array}$} & \multirow{2}{*}{$\begin{array}{c}\text { Ambient } \\
\text { Air }\end{array}$} & \multirow{2}{*}{$\begin{array}{l}\text { Aix } \\
\text { Flow } \\
\text { CFH (2) }\end{array}$} \\
\hline & & & & 1 & 2 & & & & \\
\hline $\begin{array}{l}\text { Canister } \\
+ \text { Cask }\end{array}$ & 2060 & 665 & - & 390 & - & 255 & 95 & 80 & 50,000 \\
\hline $\begin{array}{l}\text { Canister } \\
+ \text { Cask } \\
+ \text { Cask }\end{array}$ & 2120 & 725 & - & 515 & 320 & 205 & 91 & 80 & 74,000 \\
\hline $\begin{array}{l}\text { Canister } \\
+ \text { Overpack } \\
+ \text { Cask }\end{array}$ & 2220 & 825 & 630 & 355 & - & 230 & 93 & 80 & 55,000 \\
\hline $\begin{array}{l}\text { Canister } \\
+ \text { Overpack } \\
+ \text { Cask } \\
+ \text { Cask } \\
\end{array}$ & 2270 & 875 & 695 & 495 & 305 & 195 & 90 & 80 & 80,000 \\
\hline
\end{tabular}

(1) Canister has no fins and contains calcine

(2) At average annulus temperature 


\section{TABLE 4}

AIR FLOW BLOCKAGE TEMPERATURES FOR

MULTIPLE BARRIER STORAGE UNIT

CONTAINING OPTIMUM REFERENCE CANISTER

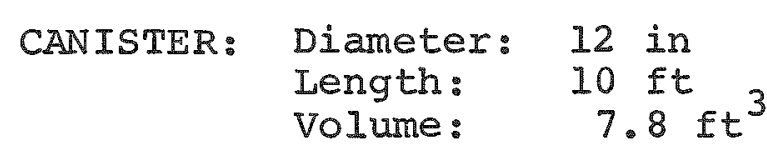

Specific Heat Generation: $1.3 \mathrm{kw} / \mathrm{ft}^{3}$ Total Heat Generation: $10.1 \mathrm{kw}$

\begin{tabular}{|c|c|c|c|c|c|c|c|c|c|}
\hline \multirow[t]{3}{*}{ CONFIGURATION } & \multicolumn{9}{|c|}{ MAXIMUM COMPONENT TEMPERATURE - ${ }^{\circ} \mathrm{F}$} \\
\hline & \multirow{2}{*}{ Waste $\mathrm{E}^{(1)}$} & \multirow[t]{2}{*}{ Canister } & \multirow[t]{2}{*}{ Overpack } & \multicolumn{2}{|c|}{ Storage Cask } & \multirow{2}{*}{$\begin{array}{l}\text { Inner } \\
\text { Shield }\end{array}$} & \multirow{2}{*}{$\begin{array}{l}\text { Outer } \\
\text { Shield }\end{array}$} & \multirow{2}{*}{$\begin{array}{l}\text { Ambient } \\
\text { Air }\end{array}$} & \multirow{2}{*}{$\begin{array}{l}\text { Air } \\
\text { Flow(2) } \\
\text { CFH }\end{array}$} \\
\hline & & & & 1 & 2 & & & & \\
\hline $\begin{array}{l}\text { Canister } \\
+ \text { Cask }\end{array}$ & 2695 & 1310 & - & 1230 & - & 1195 & 139 & 80 & 0 \\
\hline $\begin{array}{l}\text { Canister } \\
+ \text { Cask } \\
+ \text { Cask }\end{array}$ & 2625 & 1240 & - & 1145 & 1090 & 1050 & 135 & 80 & 0 \\
\hline $\begin{array}{l}\text { Canister } \\
+ \text { Overpack } \\
+ \text { Cask }\end{array}$ & 2700 & 1315 & 1225 & 1150 & - & 1115 & 137 & 80 & 0 \\
\hline $\begin{array}{l}\text { Canister } \\
+ \text { Overpack } \\
+ \text { Cask } \\
+ \text { Cask }\end{array}$ & 2655 & 1270 & 1165 & 1080 & 1030 & 990 & 133 & 80 & 0 \\
\hline
\end{tabular}

(1) Canister has no fins and contains calcine

(2) At average annulus temperature 


\section{TABLE 5}

BURIAL TEMPERATURES AT ONE MONTH FOR

MULTIPLE BARRIER STORAGE UNIT

CONTAINING OPTIMUM REFERENCE CANISTER

$\begin{array}{ll}\text { CANISTER: } & \text { Diameter: } 12 \mathrm{in} \\ \text { Length: } & 10 \mathrm{ft} \\ \text { Volume: } & 7.8 \mathrm{ft}^{3}\end{array}$

Specific Heat Generation: $1.3 \mathrm{kw} / \mathrm{ft}^{3}$ Total Heat Generation: $\quad 10.1 \mathrm{kw}$

\begin{tabular}{|c|c|c|c|c|c|c|}
\hline \multirow[t]{3}{*}{ CONFIGURATION } & \multicolumn{6}{|c|}{ MAXIMUM COMPONENT TEMPERATURE - ${ }^{\circ} \mathrm{F}$} \\
\hline & \multirow[t]{2}{*}{ Waste $q^{(I)}$} & \multirow[t]{2}{*}{ Canister } & \multirow[t]{2}{*}{ Overpack } & \multicolumn{2}{|c|}{ Storage Cask } & \multirow{2}{*}{$\begin{array}{l}\text { Inner } \\
\text { Shielo }\end{array}$} \\
\hline & & & & 1 & 2 & \\
\hline $\begin{array}{l}\text { Canister } \\
+ \text { Cask }\end{array}$ & 3375 & 1990 & - & 1965 & - & 1950 \\
\hline $\begin{array}{l}\text { Canister } \\
+ \text { Cask } \\
+ \text { Cask }\end{array}$ & 3080 & 1695 & - & 1655 & 1630 & 1615 \\
\hline $\begin{array}{l}\text { Canister } \\
+ \text { gverpack } \\
+ \text { Cask }\end{array}$ & 3230 & 1845 & 1805 & 1775 & - & 1760 \\
\hline $\begin{array}{l}\text { Canister } \\
+ \text { Overpack } \\
+ \text { Cask } \\
+ \text { Cask }\end{array}$ & 2990 & 1605 & 1550 & 1505 & 1480 & 1465 \\
\hline
\end{tabular}

(1) Canister has no fins and contains calcine 
TABLE 6

NORMAL OPERATING TEMPERATURES FOR

MULTIPLE BARRIER STORAGE UNIT

CONTAINING OPTIMUM MAXIMUM CANISTER SIZE

CANISTER: Diameter: 18.5 in

Length: $\quad 15 \mathrm{ft}^{3}$
Volume:

Specific Heat Generation: $0.55 \mathrm{kw} / \mathrm{ft}^{3}$

Total Heat Generation: $15.4 \mathrm{kw}$

\begin{tabular}{|c|c|c|c|c|c|c|c|c|c|}
\hline \multirow[t]{2}{*}{ CONFIGURATION } & \multicolumn{9}{|c|}{ MAXIMUM COMPONTENT TEMPERATURE - ${ }^{\circ} \mathrm{F}$} \\
\hline & waste $\mathcal{G}^{(1)}$ & Canister & Overpack & $\frac{\text { storage }}{1}$ & $\frac{\text { Cask }}{2}$ & $\begin{array}{l}\text { Inner } \\
\text { Shield }\end{array}$ & $\begin{array}{l}\text { Outer } \\
\text { Shield }\end{array}$ & $\begin{array}{c}\text { Ambient } \\
\text { Air }\end{array}$ & $\begin{array}{l}\text { Air } \\
\text { FIOW } \\
\text { CFH (2) }\end{array}$ \\
\hline $\begin{array}{l}\text { Canister } \\
+ \text { Cask }\end{array}$ & 1955 & 560 & - & 355 & - & 240 & 92 & 80 & 70,000 \\
\hline $\begin{array}{l}\text { Canister } \\
+ \text { Cask } \\
+ \text { Cask }\end{array}$ & 2035 & 640 & - & 470 & 305 & 200 & 89 & 80 & 76,000 \\
\hline $\begin{array}{l}\text { Canister } \\
+ \text { Overpack } \\
+ \text { Cask }\end{array}$ & 2080 & 685 & 525 & 330 & - & 225 & 91 & 80 & 103,000 \\
\hline $\begin{array}{l}\text { Canister } \\
+ \text { Overpack } \\
+ \text { Cask } \\
+ \text { Cask }\end{array}$ & 2135 & 740 & 600 & 440 & 285 & 190 & 89 & 80 & 109,000 \\
\hline
\end{tabular}

(1) Canister has no fins and contains calcine

(2) At average annulus temperature 


\section{TABLE 7}

AIR FLOW BLOCKAGE TEMPERATURES FOR

MULTIPLE BARRIER STORAGE UNIT

CONTAINING OPTIMUM MAXIMUM CANISTER SIZE

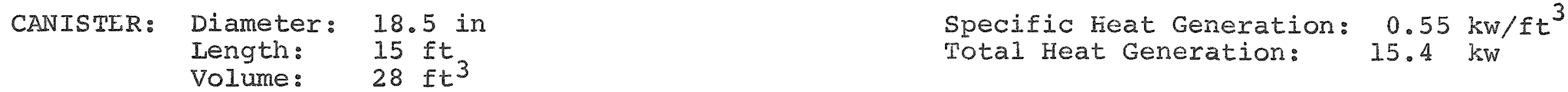

\begin{tabular}{|c|c|c|c|c|c|c|c|c|c|}
\hline \multirow{3}{*}{ CONFIGURATION } & \multicolumn{9}{|c|}{ MAXIMUM COMPOINENT TEMPERATURE - ${ }^{\circ} \mathrm{F}$} \\
\hline & \multirow{2}{*}{ Waste $\mathbb{E}^{(1)}$} & \multirow[t]{2}{*}{ Canister } & \multirow[t]{2}{*}{ Overpack } & \multicolumn{2}{|c|}{ Storage Cask } & \multirow{2}{*}{$\begin{array}{l}\text { Inner } \\
\text { Shield }\end{array}$} & \multirow{2}{*}{$\begin{array}{l}\text { Outer } \\
\text { Shield }\end{array}$} & \multirow{2}{*}{$\begin{array}{c}\text { Ambient } \\
\text { Air }\end{array}$} & \multirow{2}{*}{$\begin{array}{l}\text { Air } \\
\text { FIOW } \\
\text { CFII }(2)\end{array}$} \\
\hline & & & & 1 & 2 & & & & \\
\hline $\begin{array}{l}\text { Canister } \\
+ \text { Cask }\end{array}$ & 2595 & 1200 & - & 1135 & - & 1105 & 135 & 80 & 0 \\
\hline $\begin{array}{l}\text { Canister } \\
+ \text { Cask } \\
+ \text { Cask }\end{array}$ & 2545 & 1150 & - & 1080 & 1035 & 1000 & 132 & 80 & 0 \\
\hline $\begin{array}{l}\text { Canister } \\
+ \text { Overpack } \\
+ \text { Cask }\end{array}$ & 2610 & 1215 & 1140 & 1080 & - & 1045 & 134 & 80 & 0 \\
\hline $\begin{array}{l}\text { Canister } \\
+ \text { Overpack } \\
+ \text { Cask } \\
+ \text { Cask }\end{array}$ & 2575 & 1180 & 1095 & 1030 & 985 & 950 & 131 & 80 & 0 \\
\hline
\end{tabular}
(1) Canister has no fins and contains calcine
(2) At average annulus temperature 
BURIAL TEMPERATURES AT ONE MONTH FOR

MULTIPLE BARRIER STORAGE UNIT

CONTAINING OPTIMUM MAXIMUM CANISTER SIZE

$\begin{array}{ll}\text { CANISTER: } & \begin{array}{l}\text { Diameter: } \\ \text { Length: }\end{array} \\ & 15.5 \mathrm{in} \\ \text { Volume } & 28 \mathrm{ft}\end{array}$

Specific Heat Generation: $0.55 \mathrm{kw} / \mathrm{ft}^{3}$ Total Heat Generation: $15.4 \mathrm{kw}$

\begin{tabular}{|c|c|c|c|c|c|c|}
\hline \multirow[t]{2}{*}{ CONFIGURAIION } & \multicolumn{6}{|c|}{ MAXIMUM COMPONENT TEMPERATURE - ${ }^{\circ} F$} \\
\hline & Waste $\varepsilon^{(1)}$ & Canister & Overpack & $\begin{array}{c}\text { storage } \\
1\end{array}$ & $\frac{\text { Cask }}{2}$ & $\begin{array}{l}\text { Inner } \\
\text { Shield }\end{array}$ \\
\hline $\begin{array}{l}\text { Canister } \\
+ \text { Cask }\end{array}$ & 3070 & 1675 & - & 1650 & 0 & 1635 \\
\hline $\begin{array}{l}\text { Canister } \\
+ \text { Cask } \\
+ \text { Cask }\end{array}$ & 2850 & 1455 & - & 1410 & 1385 & 1370 \\
\hline $\begin{array}{l}\text { Canister } \\
+ \text { Qverpack } \\
+ \text { Cask }\end{array}$ & 2965 & 1570 & 1530 & 1500 & - & 1485 \\
\hline $\begin{array}{l}\text { Canister } \\
+ \text { Overpack } \\
+ \text { Cask } \\
+ \text { Cask }\end{array}$ & 2785 & 1390 & 1335 & 1295 & 1270 & 1250 \\
\hline
\end{tabular}

(1) Canister has no fins and contains calcine 


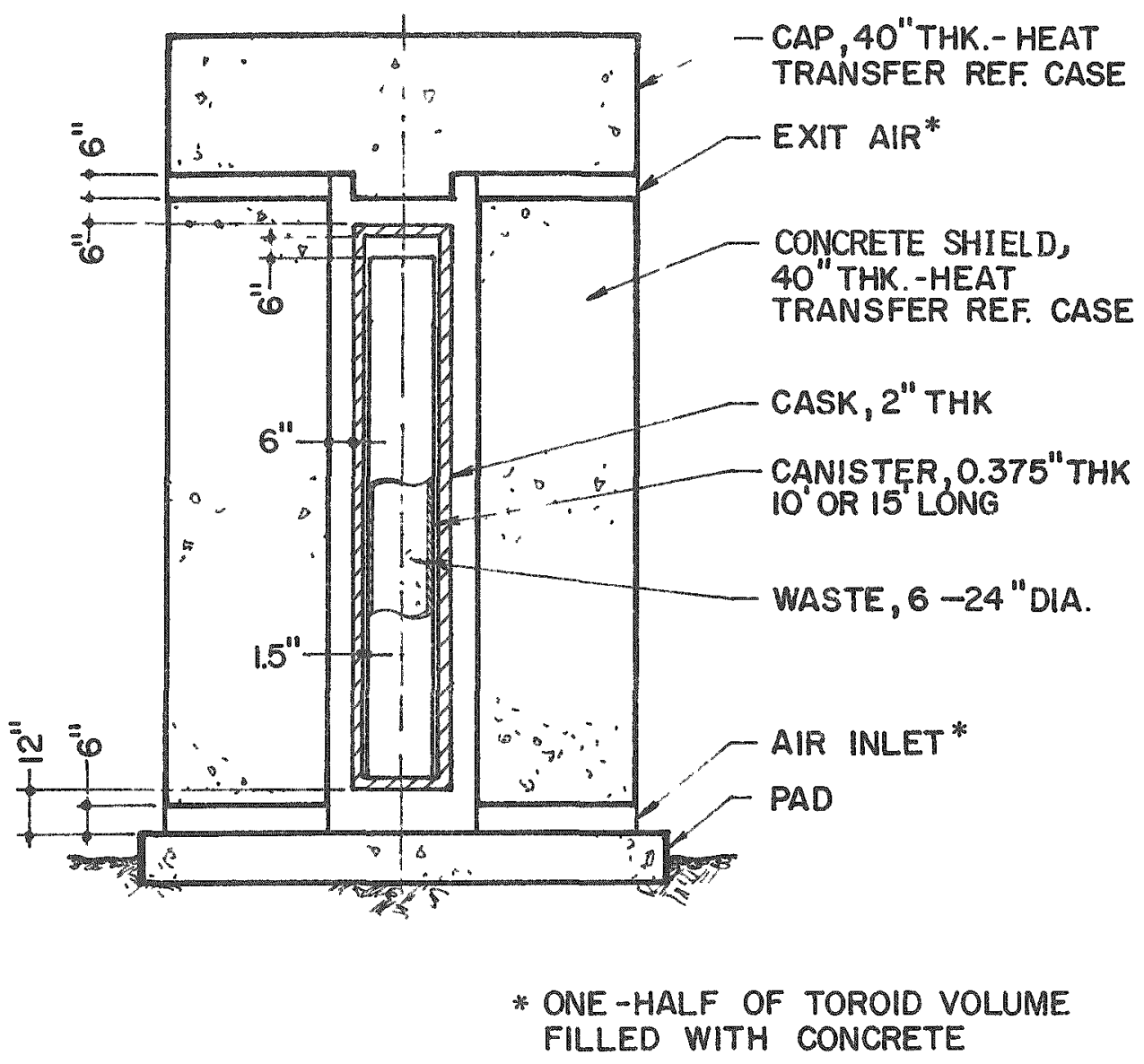

FIGURE 1

SEALED STORAGE CASK CONCEPT

GENERIC WASTE STORAGE UNIT

NORMAL OPERATION 
SPECIFIC WASTE VOLUME, FT $3 /$ MT
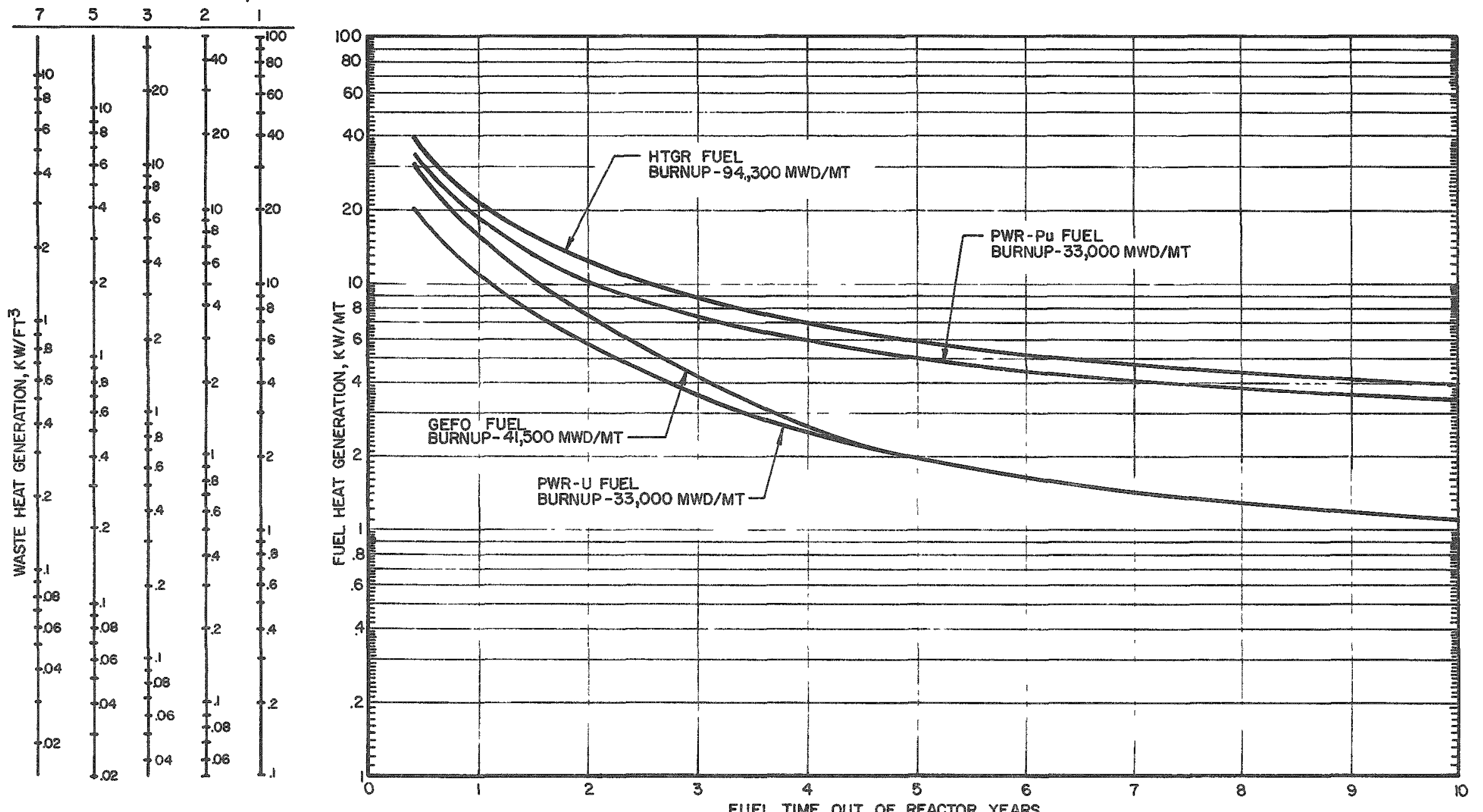

FIGURE 2

HIGH LEVEL WASTE HEAT GENERATION

FOR REFERENCE FUELS 


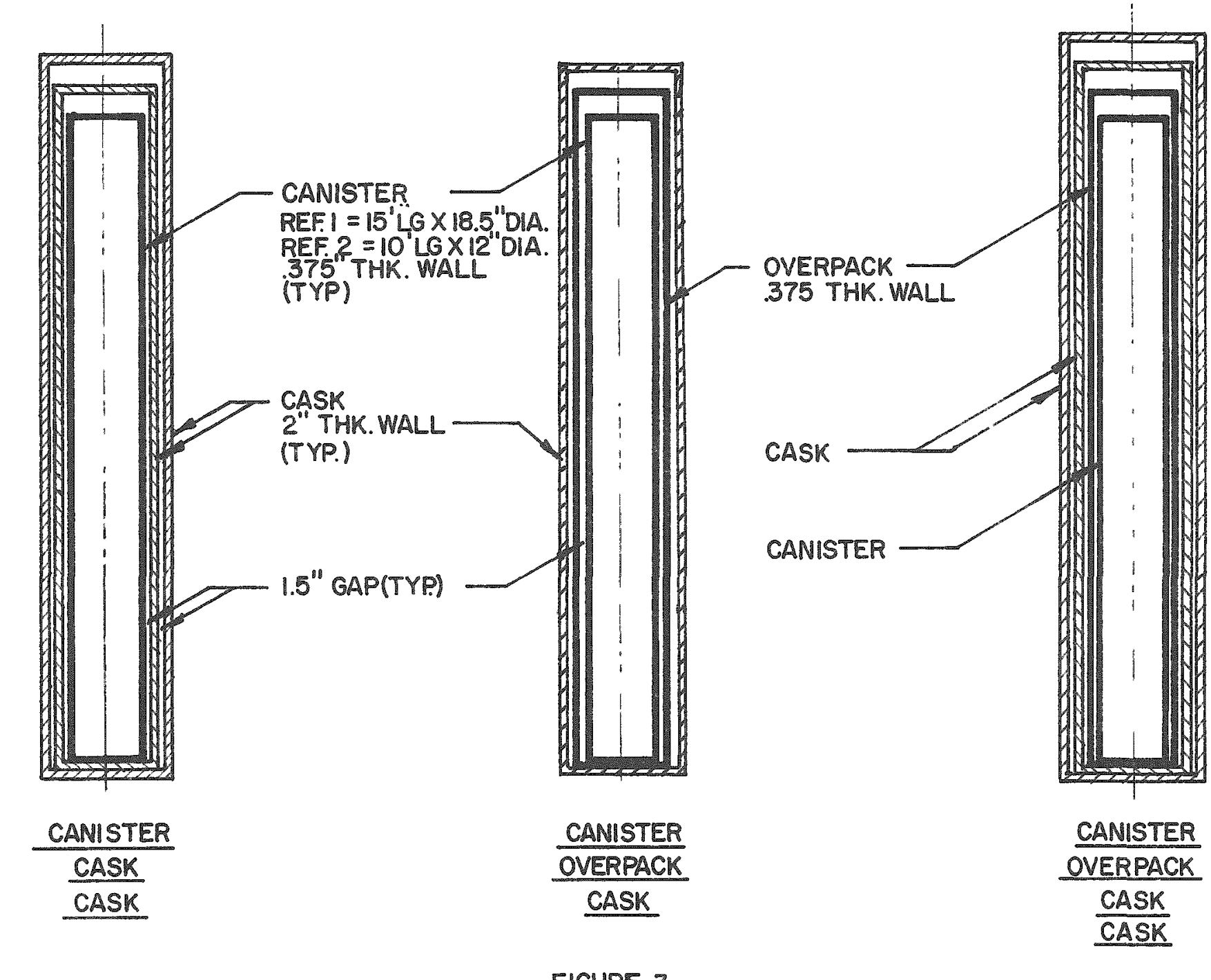

U

MULTIPLE OVERPACK CONFIGURATIONS 

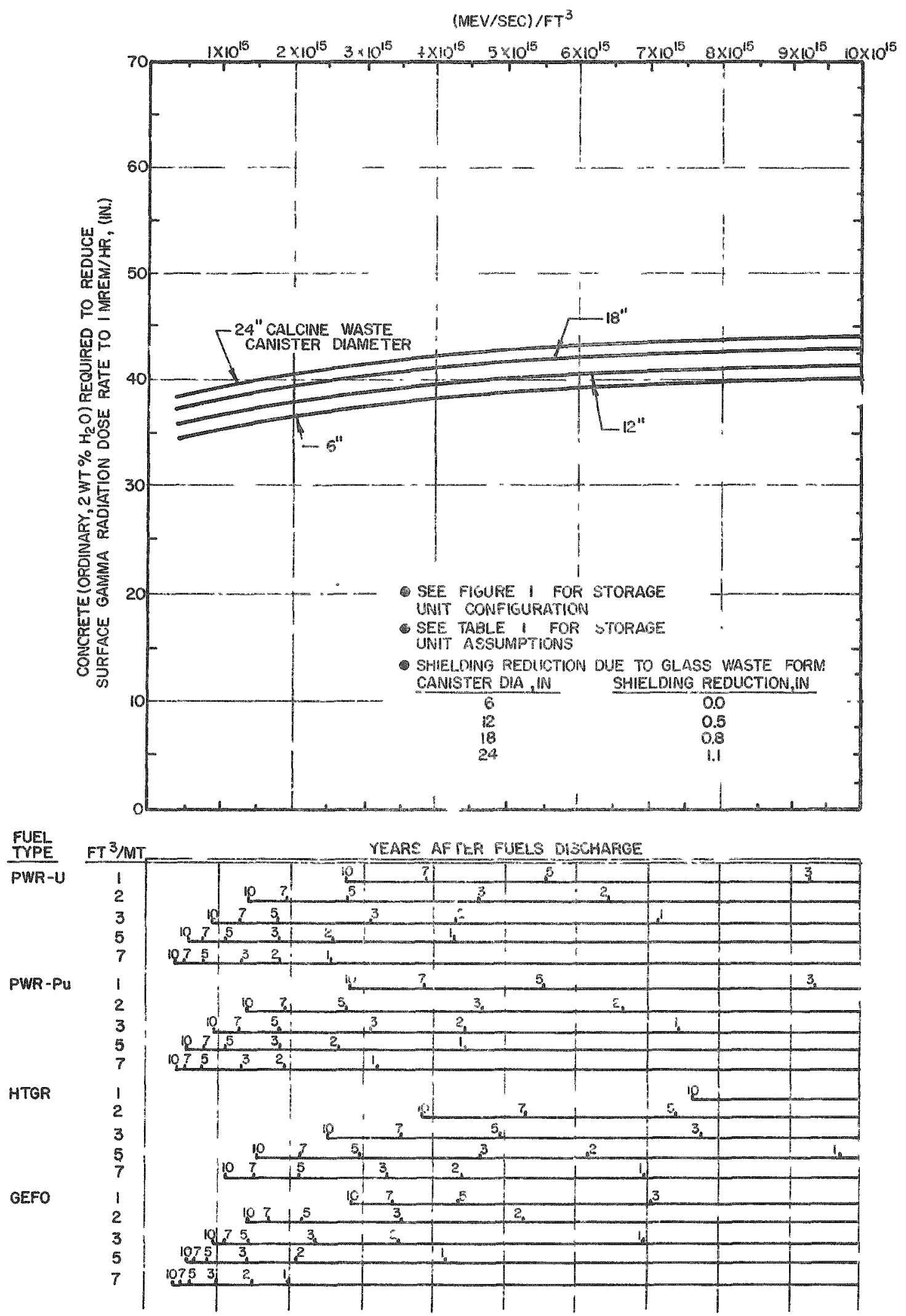

FIGURE 4 


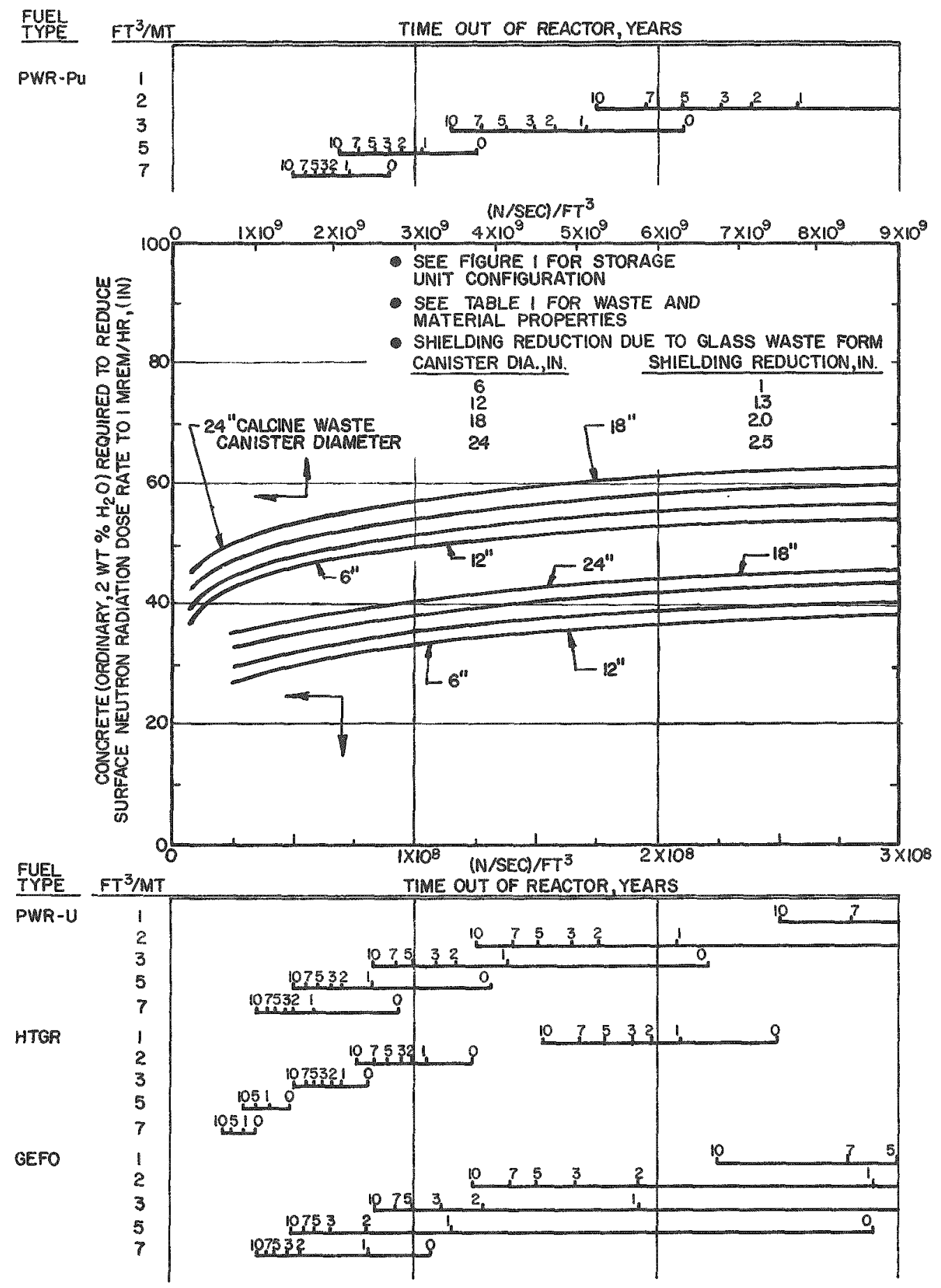

FIGURE 5 


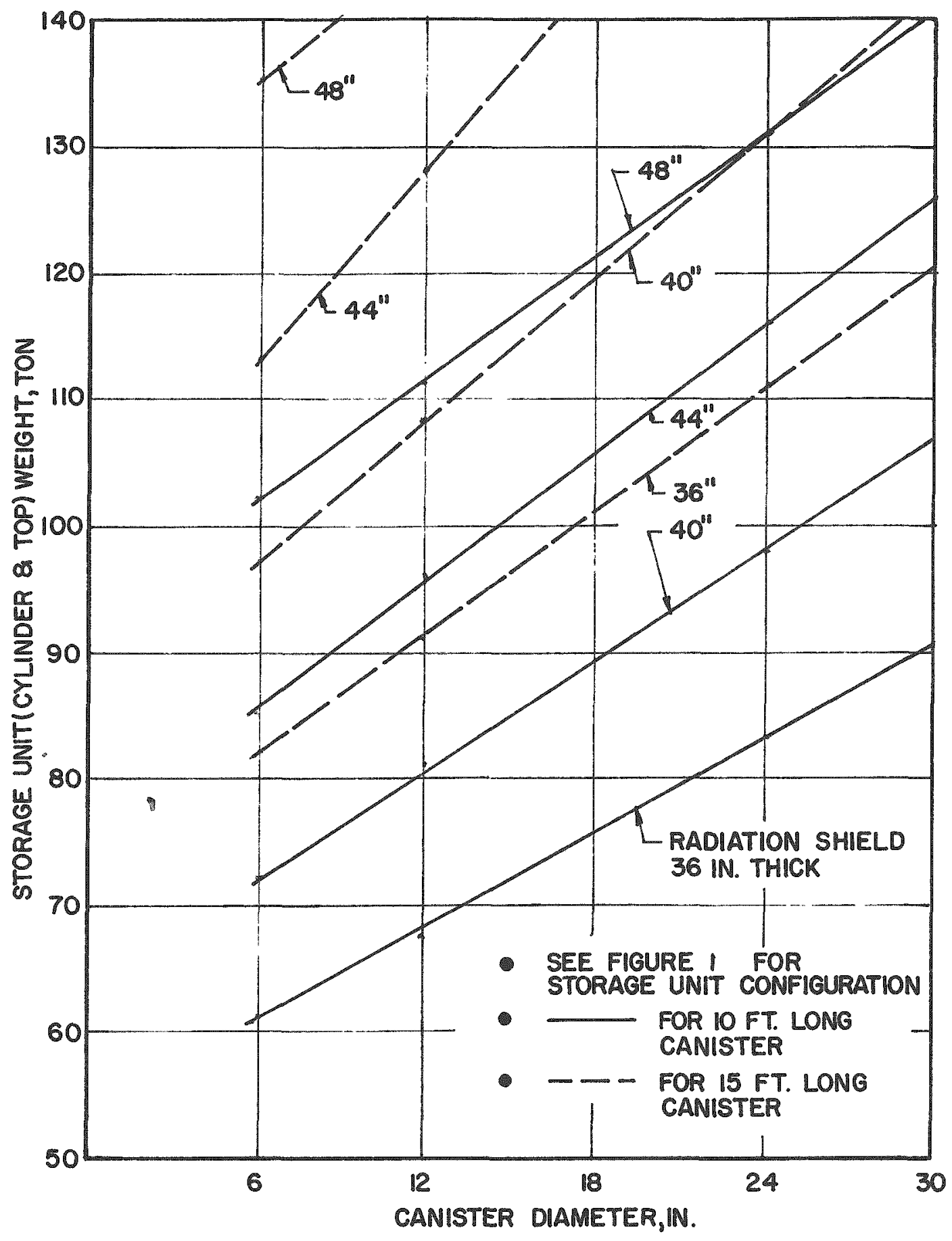

FIGURE 6

SEALED STORAGE CASK CONCEPT STORAGE UNIT WEIGHT FOR VARIABLE CANISTER DIMENSIONS 
APPENDIX A

EFEECTS OF NUCLEAR FUEL PROPERIIES ON WASTE HEAT GENERATION

The effects of four different fuel types and their degree of burnup on waste heat generation was determined. The heat generation was determined as a function of time after fuel discharge. Calculations were made with the "ORIGN" computer code assuming average fuel properties and constant exposure conditions. The heat generation data was translated into waste heat generation properties by assuming that all radiation and other energy from the fission products and actinides in the waste are converted to thermal energy in the waste and generated from it. It was assumed that 0.5 percent of the uranium and plutonium from the fuels was in the waste for all cases except the High Temperature Gas Cooled Reactor waste where 0.5 percent of the uranium and thorium was in the waste. The results are shown in the figures indicated below.

\section{Fuel Type}

Pressurnized Water Reactor - Enriched

Uranium Fuel (PWR-U)

Pressurized Water Reactor - Equilibrium

Recycle Enriched Plutonium Fuel (PWR-Pu)

High Temperature Gas Cooled Reactor -

Equilibrium Recycle Fuel (HTGR)

Liquid Metal Fast Breeder Reactor -

Equilibrium Recycle Fuel (GEFO)
Figure

$A-1$

$A-2$

$A-3$

$A-4$

Equilibrium recycle fuel characteristics were used since they represent worst case properties for heat generation and radiation characteristics. The effect of different enrichments of PWR U fuels on heat generation characteristics at various fuel exposures was reviewed, Table $\mathrm{A}-1$. It is seen that enrichment does not significantly affect the heat generation rate. The effect of power level on fuel heat generation was not investigated, 
but it would be expected that the heat generation would be somewhat higher at short times out of the reactor for higher levels and constant burnup. 
TABLE $A-1$

EFEECT OF ENRICHMENT ON EXPOSED PWR-U FUEL HEAT GENLRATIOIN AND RADIATION PROPERTIES

Power Level - $30 \mathrm{MW} / \mathrm{Mr}$

\begin{tabular}{|c|c|c|c|c|c|c|c|c|c|c|c|}
\hline \multirow{4}{*}{$\begin{array}{l}\text { Exposure } \\
\text { MWD/MT }\end{array}$} & \multirow{4}{*}{\multicolumn{2}{|c|}{$\begin{array}{l}\text { Enrichment } \\
\therefore \mathrm{U}-235\end{array}$}} & \multicolumn{9}{|c|}{ Property } \\
\hline & & & \multicolumn{3}{|c|}{$\begin{array}{c}\text { Heat Generation } \\
\text { KW/MT }\end{array}$} & \multicolumn{3}{|c|}{$\begin{array}{c}\text { Gamma Radiation } \\
\text { Mev/sec-MT }\end{array}$} & \multicolumn{3}{|c|}{$\begin{array}{c}\text { IJeutron Generation } \\
\mathrm{N} / \mathrm{sec}-\mathrm{P} H \mathrm{~T}\end{array}$} \\
\hline & & & \multicolumn{3}{|c|}{ Years After Discharge } & \multicolumn{3}{|c|}{ Years After Discharge } & \multicolumn{3}{|c|}{ Years AEter Discharge } \\
\hline & & & 1 & 3 & 10 & 1 & 3 & 10 & 1 & 3 & 10 \\
\hline \multirow[t]{2}{*}{15,000} & & 3.3 & 6.12 & 1.66 & 0.484 & $9.5 \times 10^{15}$ & $3.1 \times 10^{15}$ & $1.1 \times 10^{15}$ & $9.9 \times 10^{6}$ & $5.2 \times 10^{6}$ & $3.8 \times 10^{6}$ \\
\hline & & 2.05 & 6.64 & 1.82 & 0.475 & $1.1 \times 10^{16}$ & $3.7 \times 10^{15}$ & $1.2 \times 10^{15}$ & $3.9 \times 10^{7}$ & $2.6 \times 10^{7}$ & $1.9 \times 10^{7}$ \\
\hline \multirow[t]{2}{*}{20,000} & & 3.3 & 7.50 & 2.18 & 0.646 & $1.2 \times 10^{16}$ & $4.6 \times 10^{15}$ & $1.5 \times 10^{15}$ & $3.9 \times 10^{7}$ & $2.4 \times 10^{7}$ & $1.8 \times 10^{7}$ \\
\hline & & 2.4 & 7.99 & 2.35 & 0.644 & $1.4 \times 10^{16}$ & $5.2 \times 10^{15}$ & $1.6 \times 10^{15}$ & $9.5 \times 10^{7}$ & $6.7 \times 10^{7}$ & $3.1 \times 10^{7}$ \\
\hline \multirow[t]{2}{*}{40,000} & & 3.3 & 12.6 & 4.47 & 1.42 & $2.7 \times 10^{10}$ & $1.2 \times 10^{16}$ & $3.4 \times 10^{15}$ & $9.9 \times 10^{8}$ & $8.3 \times 10^{8}$ & $0.3 \times 10^{8}$ \\
\hline & & 3.8 & 12.1 & 4.28 & 1.39 & $2.5 \times 10^{16}$ & $1.2 \times 10^{16}$ & $3.4 \times 10^{15}$ & $7.0 \times 10^{8}$ & $5.7 \times 10^{8}$ & $4.4 \times 10^{8}$ \\
\hline
\end{tabular}


SPECIFIC WASTE VOLUME, FT $3 / M T$
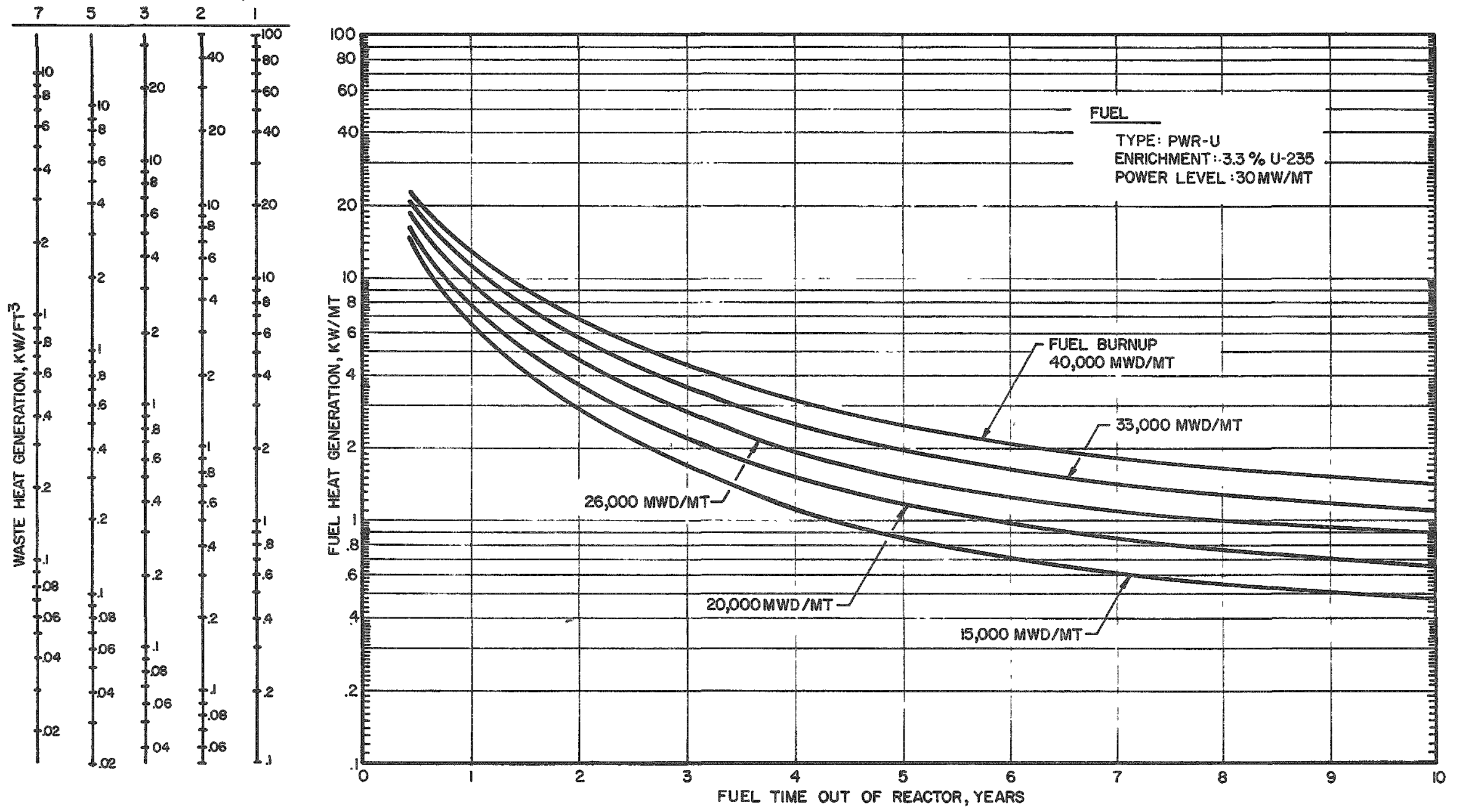

FIGURE A-1

HIGH LEVEL WASTE HEAT GENERATION

WASTE SOURCE : PWR-U FUEL 

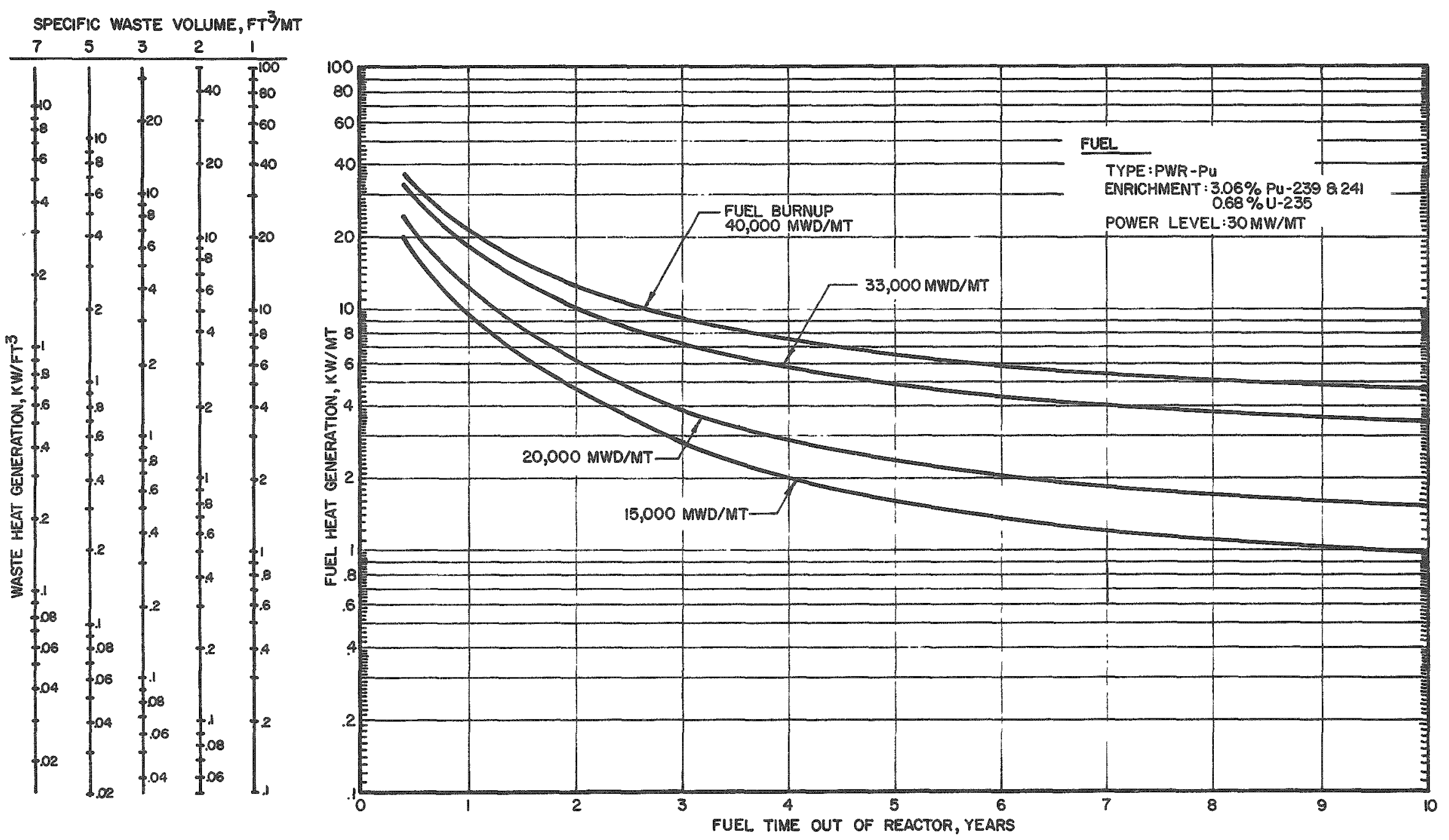

FIGURE A-2

HGH LEVEL MASTE HEAT GENERATION

WASTE SOURCE: PWR-PU FUEL 

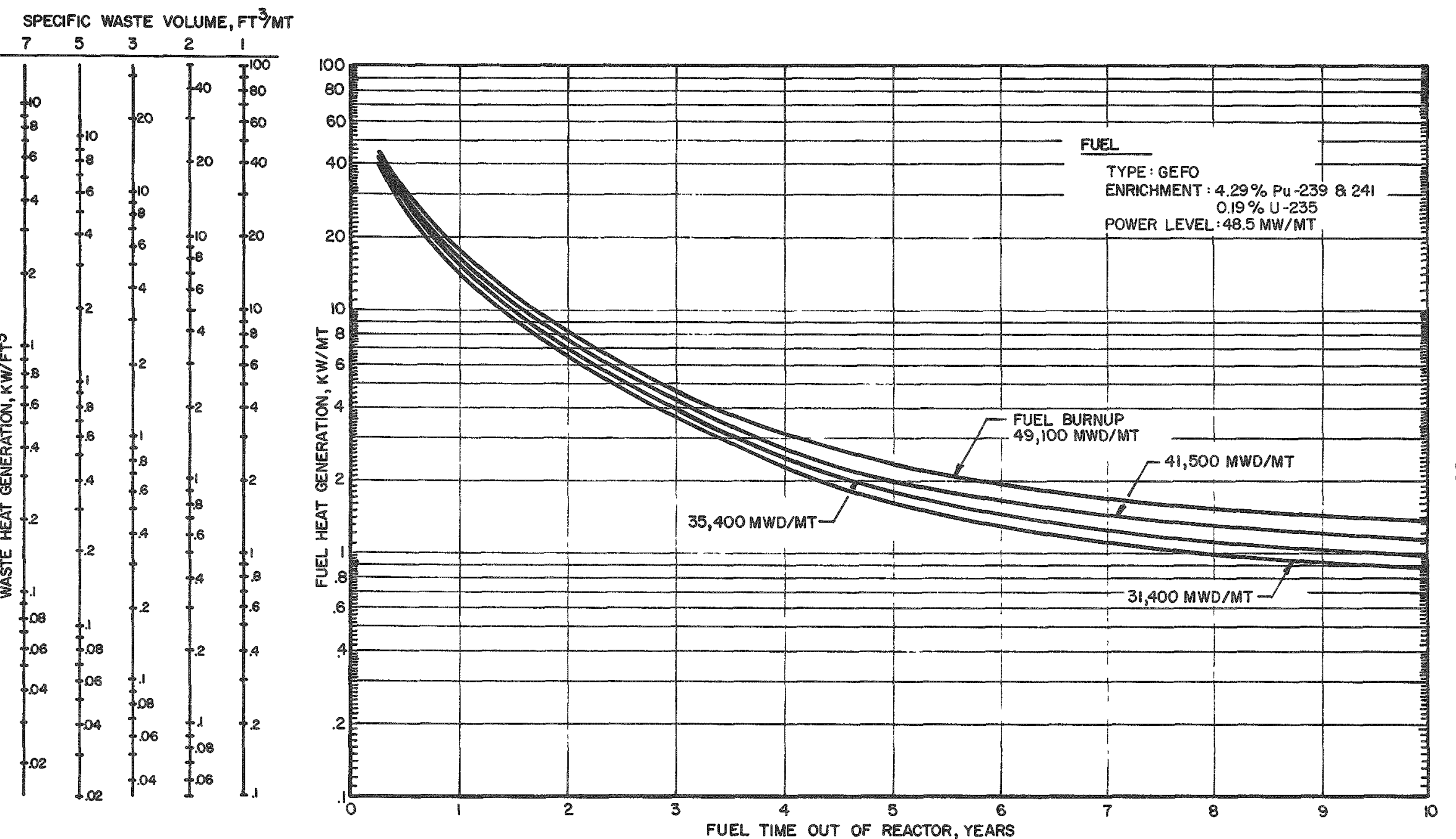

FIGURE A-3

HIGH LEVEL WASTE HEAT GENERATION

WASTE SOURCE : GEFO FUEL 
SPECIFIC WASTE VOLUME, FT'3/MT
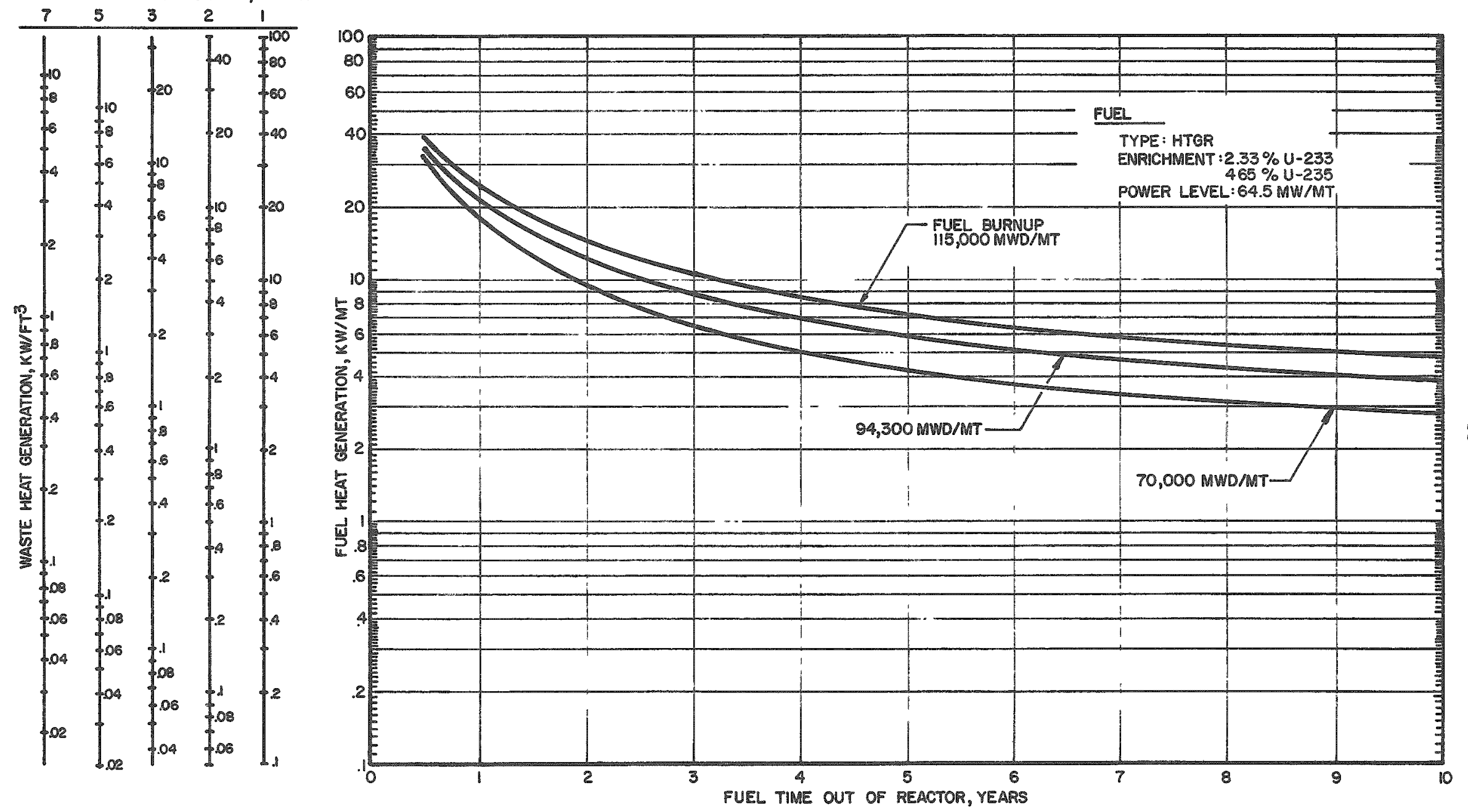

FIGURE A-4

HIGH LEVEL WASTE HEAT GENERATION

WASTE SOURCE: HTGR FUEL 
APPENDIX B

HIGH LEVEL WASTE STORAGE UNIT THERMAL ANALYSES RESULTS

Three situations, normal operation, air flow stoppage and burial, were analyzed for material temperature limitations that may be encountered in the storage unit. The limitation for these circumstances is the storage unit material property which would impair the storage unit integrity. For an abnormal situation the radiation shield integrity was not considered necessary for waste containment and is not considered limiting. The materials limitations and the associated bases are shown in Table B-7. Storage unit assumptions and characteristics are stated in Table 1. The canister heat generation rate range of 0.25 to 3 kilowatts per cubic foot is presented. Models used for calculations were two dimensional and included conduction, convection, and radiation heat transfer modes.

The results are shown in the figures indicated below for the appropriate situations.

Situation

Figure

Normal Operation (Figure B-19)

Canister:

Length; 10, 15 feet Diameter, inches $\quad B-2$

$6 \quad B-1$

$12 \quad B-2$

$18 \quad B-3$

$24 \quad B-4$

Air Flow Stoppage (Figure B-5)

Canister:

Length, feet 10
Diameter, inches

$B-6$

12

$B-7$

18

$B-8$ 
Situation

Figure

Air Flow Stoppage (continued)

Canister:

Length, feet

10

15 $\frac{\text { Diameter, inches }}{24}$

6

12

18

24
$B-9$

$B-10$

$B-11$

$B-12$

$B-13$

Burial (Figure 14)

Canister:

Length, feet

10
Diameter, inches

$\begin{array}{rl}6 & B-15 \\ 12 & B-16 \\ 18 & B-17 \\ 24 & B-18\end{array}$

The results for the buried storage unit containing the 15 foot long canister are essentially the same as for the 10 foot long canister and are not included.

To determine the filled waste canister characteristics that may be received at the RSSF, based on materials limitations, the following scheme may be used with the above figures. In the appropriate figure find the maximum allowable material temperature furthest toward the left hand side of the figure. Then all the waste types at the cubic foot per metric ton and waste age to the left of that temperature are allowable for receiption at the RSSF. The exposure and fuel assumptions from which the waste came are indicated in Table B-8. The burial case conditions are not considered limiting since this accident is not deemed credible. It should be noted that for the burial cases considered which are more restrictive than the no air 
flow cases on canister heat content, that there is a time period over which the canister can be ehxumated intact. For normal operating situation, waste temperatures in canisters without fins, air flow rates through the storage unit, and the number of canister fins required to maintain the waste below its maximum stable temperature are shown in Table B-2 through B-6 for calcine and glass waste in 10 and 15 foot long canisters. The waste temperatures encountered at the canister wall is below the maximum stable waste temperature for credible situations encountered in the RSSF. Additional studies are needed to determine if this is adequate. That is, verification is needed to establish that pressurization and increased corrosion rates will not be significant under abnormal conditions due to the high waste centerline temperature, possibly above the maximum stable temperature of the waste. 
TABLE B-1

SEALED STORAGE CASK CONCEPT
MATERIAL TEMPERATURE LIMITATIONS IN AIR

$\begin{array}{cc}\operatorname{cormal}_{\text {Operation (1) }} & \begin{array}{c}\text { Abnormal (2) } \\ \text { Operation }\end{array} \\ 500^{\circ} \mathrm{F}^{(3)} & 900^{\circ} \mathrm{F}^{(4)} \\ 600^{\circ} \mathrm{F}^{(5)} & 1200^{\circ} \mathrm{F}^{(6)} \\ 800^{\circ} \mathrm{F}^{(7)} & 1500^{\circ} \mathrm{F}^{(8)}\end{array}$

Bases: (1) Maximum allowable temperatures during 100 year design life that will not compromise containment integrity;

(2) Maximum allowable temperature for up to one year where immediate containment integrity would not be impaired, but integrity could not be assured for 100 years:

(3) Twenty percent loss of strength;

(4) Extensive cracking with significant loss of strength. Concrete would require replacement;

(5) Maximum oxidation rate of 2 mils/year;

(6) Upper limit of carbon steel usefulness in air, however, under zero air flow conditions oxidation rate would be low. There would be some loss of ductility due to carbide spheroidation;

(7) Grain boundary attack by cesium oxide in calcine waste would be accelerated above $850^{\circ} \mathrm{F}$ :

(8) Mechanical and fatigue properties decreased significantly. 


\section{TABLE $B-2$}

CALCINE WASTE CANISTER THERMAL DATA

AND STORAGE UNIT AIR FLOW RATES

CANISTER INENGTH - $10 \mathrm{ft}$

\begin{tabular}{|c|c|c|c|c|c|}
\hline \multirow{2}{*}{$\begin{array}{l}\text { Waste Heat } \\
\text { Generation } 3) \\
\text { Rate }\left(\mathrm{kw} / \mathrm{ft}^{3}\right.\end{array}$} & \multirow{2}{*}{ Storage Unit Data } & \multicolumn{4}{|c|}{$\begin{array}{c}\text { Canister Diameter } \\
\text { (inches) }\end{array}$} \\
\hline & & 6 & 12 & 18 & 24 \\
\hline 0.25 & $\begin{array}{l}\text { Maximum Temp. - Canister Wall, }{ }^{\circ} \mathrm{F} \\
\text { - Waste } \mathrm{E},{ }^{\circ} \mathrm{F} \\
\text { Fins Required, No. (I) } \\
\text { Storage Unit Air Flow, CFH }{ }^{(2)}\end{array}$ & $\begin{array}{r}151 \\
218 \\
0 \\
13,900\end{array}$ & $\begin{array}{r}294 \\
516 \\
0 \\
27,500\end{array}$ & $\begin{array}{r}341 \\
941 \\
0 \\
42,400\end{array}$ & $\begin{array}{r}408 \\
1,474 \\
0 \\
58,500\end{array}$ \\
\hline 0.50 & $\begin{array}{l}\text { Maximum Temp. Canister Wall, }{ }^{\circ} \mathrm{F} \\
\text { - Waste }{ }^{\circ}{ }^{\circ} \mathrm{F} \\
\text { Fins Required, No. (1) } \\
\text { Storage Unit Air Flow, } \mathrm{CFH}^{(2)}\end{array}$ & $\begin{array}{r}213 \\
346 \\
0 \\
17,900\end{array}$ & $\begin{array}{r}317 \\
910 \\
0 \\
35,400\end{array}$ & $\begin{array}{r}514 \\
1,714 \\
2 \\
54,500\end{array}$ & $\begin{array}{r}613 \\
2,747 \\
11 \\
75,400\end{array}$ \\
\hline 1.0 & $\begin{array}{l}\text { Maximum Temp. - Canister Wall }{ }^{\circ} \mathrm{F} \\
\text { - Waste }{ }^{\circ} \mathrm{F} \\
\text { Fins Required, No. (1) } \\
\text { Storage Unit Air Flow, CFH }\end{array}$ & $\begin{array}{r}321 \\
588 \\
0 \\
23,000 \\
\end{array}$ & $\begin{array}{r}568 \\
1,635 \\
2 \\
45,400 \\
\end{array}$ & $\begin{array}{r}753 \\
3,153 \\
15 \\
70,300 \\
\end{array}$ & $\begin{array}{r}889 \\
5,157 \\
245 \\
97,900 \\
\end{array}$ \\
\hline 2.0 & $\begin{aligned} & \text { Maximum Temp. } \text { - Canister Wall, }{ }^{\circ} \mathrm{F} \\
&- \text { Waste }{ }^{\circ}{ }^{\circ} \mathrm{F} \\
& \text { Fins Required, No. }(1) \\
& \text { Storage Unit Air Flow, } \mathrm{CFH}(2) \\
&\end{aligned}$ & $\begin{array}{r}490 \\
1,023 \\
0 \\
29,600\end{array}$ & $\begin{array}{r}822 \\
2,956 \\
14 \\
58,700\end{array}$ & $\begin{array}{r}1,069 \\
5,870 \\
250 \\
91,700\end{array}$ & \\
\hline 5.0 & $\begin{aligned} \text { Maximum Temp. } & \text { - Canister Wall, }{ }^{\circ} \mathrm{F} \\
& - \text { Waste } \mathcal{G},{ }^{\circ} \mathrm{F} \\
\text { Fins Required, No. (1) } & \\
\text { Storage Unit Air Flow, } \mathrm{CFH} & (2)\end{aligned}$ & $\begin{array}{r}813 \\
2,147 \\
6 \\
41,400\end{array}$ & & & \\
\hline
\end{tabular}

(1) To reduce \& temperature to $1500^{\circ} \mathrm{F}$

(2) At average annulus temperature 
TABLE B-3

CALCINE WASTE CANISTER THERMAI DATA AND STORAGE UNIT AIR FLOW RATES

CANISTER LENGTH - 15 ft

Waste Heat

Generation 3

Rate $\left(\mathrm{kw} / \mathrm{ft}^{3}\right)$

Storage unit Data

Canister Diameter

\begin{tabular}{|c|c|c|c|c|c|}
\hline Rate (kv & & 6 & 12 & 18 & 24 \\
\hline 0.25 & $\begin{array}{l}\text { Maximum Temp. - Canister Wall, }{ }^{\circ} \mathrm{F} \\
\text { - Waste } \mathrm{G},{ }^{\circ} \mathrm{F} \\
\text { Fins Required, No. (1) } \\
\text { Storage Unit Air Flow, CFH }\end{array}$ & $\begin{array}{r}161 \\
228 \\
0 \\
21,000\end{array}$ & $\begin{array}{r}261 \\
528 \\
0 \\
36,000\end{array}$ & $\begin{array}{r}356 \\
956 \\
0 \\
55,000\end{array}$ & $\begin{array}{r}427 \\
1,493 \\
0 \\
76,000\end{array}$ \\
\hline 0.50 & $\begin{array}{l}\text { Maximum Temp. - Canister WaIl, }{ }^{\circ} \mathrm{F} \\
\text { - Waste }{ }^{\circ}{ }^{\circ} \mathrm{F} \\
\text { Fins Required, No. (1) } \\
\text { Storage Unit Air Flow, CFH }{ }^{(2)}\end{array}$ & $\begin{array}{r}225 \\
358 \\
0 \\
25,000\end{array}$ & $\begin{array}{r}393 \\
926 \\
0 \\
46,000\end{array}$ & $\begin{array}{r}535 \\
1,735 \\
2 \\
70,000\end{array}$ & $\begin{array}{r}639 \\
2,773 \\
98,000\end{array}$ \\
\hline 1.0 & $\begin{aligned} & \text { Maximum Temp. } \text { - Canister Wall, }{ }^{\circ} \mathrm{F} \\
&- \text { Waste }{ }^{\circ},{ }^{\circ} \\
& \text { Fins Required, No. }(1) \\
& \text { Storage Unit Air Flow, CFH }\end{aligned}$ & $\begin{array}{r}335 \\
602 \\
0 \\
30,000 \\
\end{array}$ & $\begin{array}{r}587 \\
1,654 \\
2 \\
59,000 \\
\end{array}$ & $\begin{array}{r}780 \\
3,180 \\
15 \\
91,000 \\
\end{array}$ & \\
\hline 2.0 & $\begin{array}{l}\text { Maximum Temp. - Canister Wall, }{ }^{\circ} \mathrm{F} \\
\text { - Waste } \mathrm{q}^{\circ}{ }^{\circ} \mathrm{F} \\
\text { Fins Required, No. (1) } \\
\text { Storage Unit Air Flow, CFH }\end{array}$ & $\begin{array}{r}506 \\
1,039 \\
0 \\
38,000\end{array}$ & $\begin{array}{r}848 \\
2,982 \\
14 \\
76,000\end{array}$ & & \\
\hline 5.0 & $\begin{array}{l}\text { Maximum Temp. - Canister Wall, }{ }^{\circ} \mathrm{F} \\
\text { - Waste } \mathrm{E},{ }^{\circ} \mathrm{F} \\
\text { Fins Required, No. (1) } \\
\text { Storage Unit Air Flow, CFH (2) }\end{array}$ & $\begin{array}{r}831 \\
2,165 \\
6 \\
53,000\end{array}$ & & & \\
\hline
\end{tabular}

(1) To reduce $\varepsilon$ temperature to $1500^{\circ} \mathrm{F}$

(2) At average annulus temperature 
GLASS WASTE CANISTER THERMAL DATA AND STORAGE UNIT AIR FLOW RATES

CANISTER LENGTH - $10 \mathrm{ft}$

Waste Heat

Generation

Rate $\left(\mathrm{kw} / \mathrm{ft}^{3}\right)$

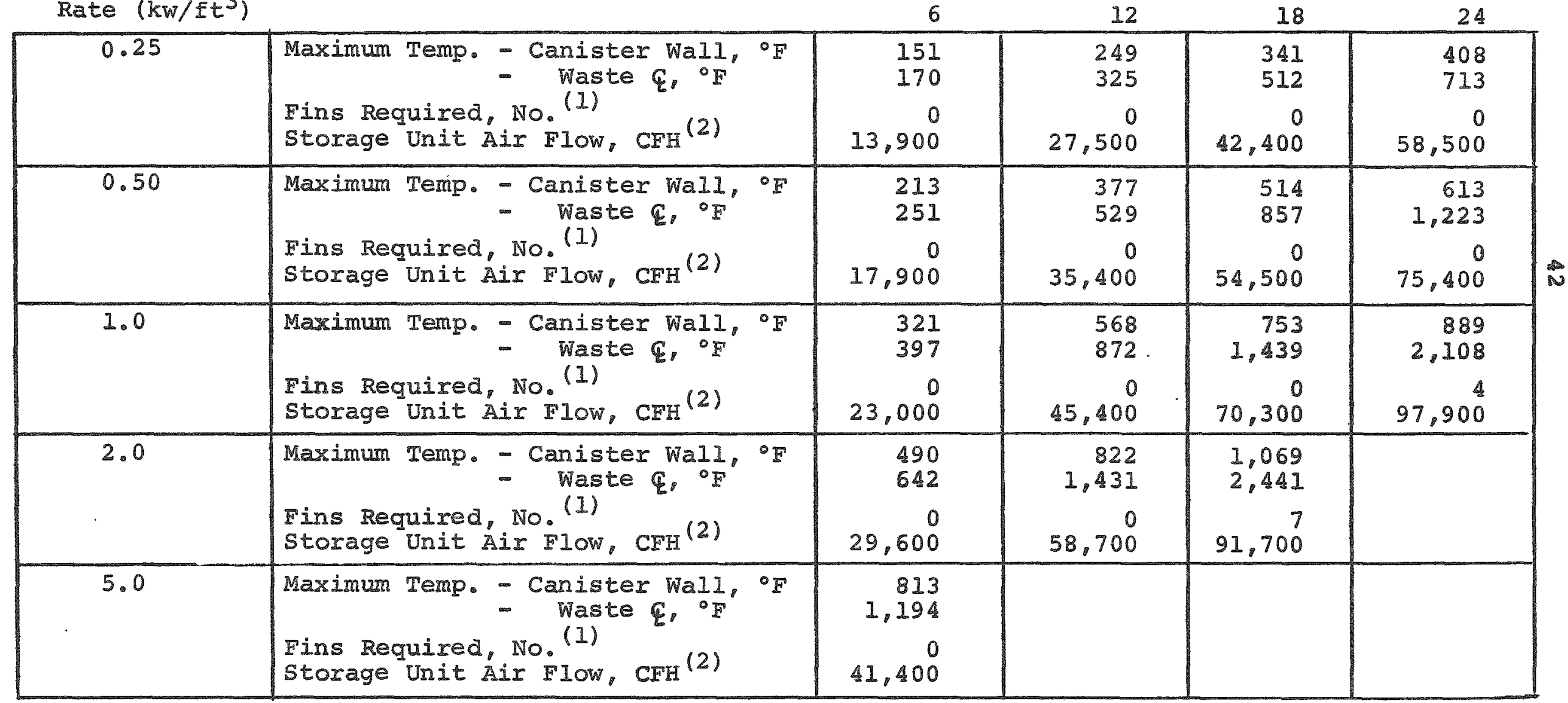

Canister Diameter

(Inches)

Storage Unit Data

(1) To reduce $\mathbb{E}$ temperature to $1900^{\circ} \mathrm{F}$

(2) To average annulus temperature 
TABLE B-5

GLASS WASTE CANISTER THERMAL DATA AND STORAGE UNIT AIR FLOW RATES

CANISTER LENGTH - $15 \mathrm{ft}$

Waste Heat Generation Rate $\left(\mathrm{kw} / \mathrm{ft} \mathrm{t}^{3}\right)$ Canister Diameter

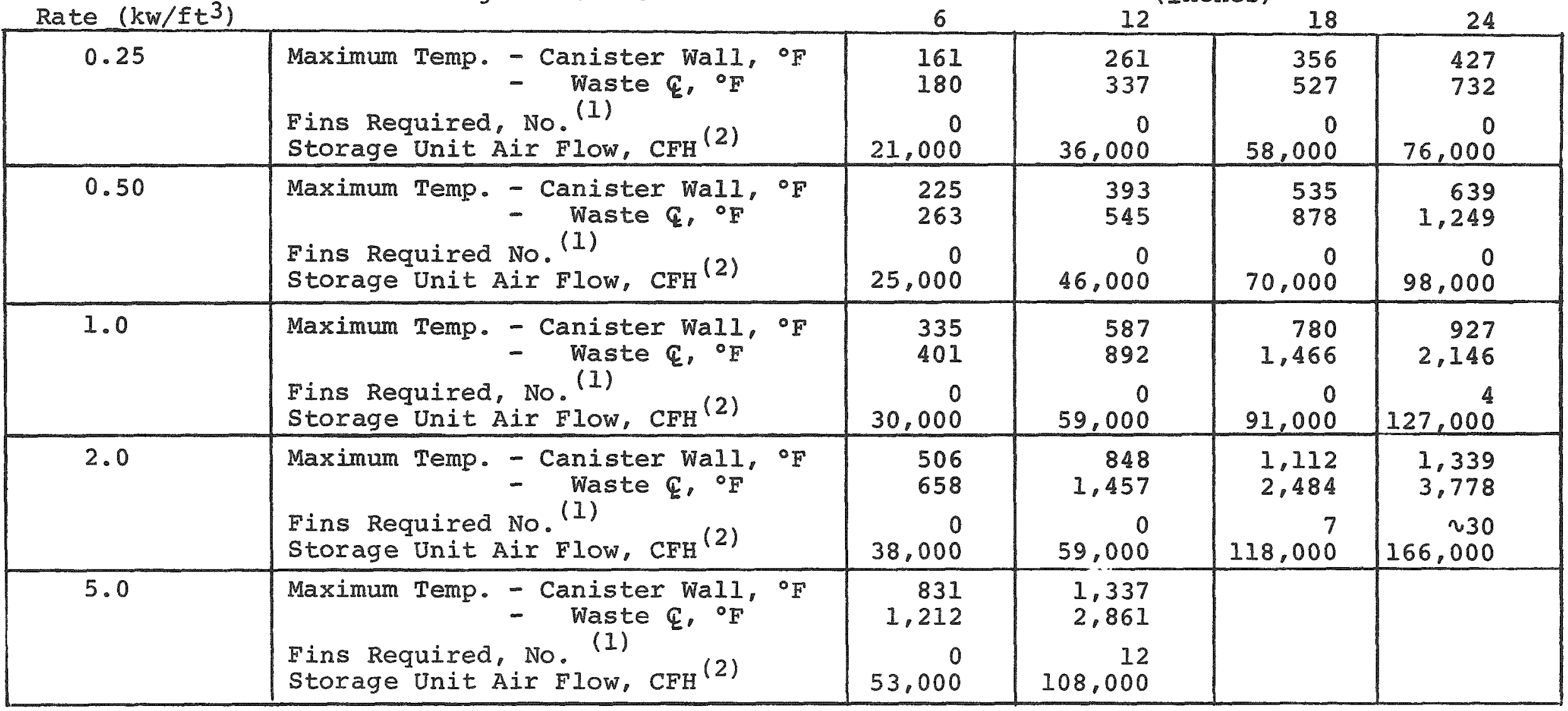

(1) To reduce $\mathcal{E}$ temperature to $1900^{\circ} \mathrm{F}$.

(2) At average annulus temperature. 


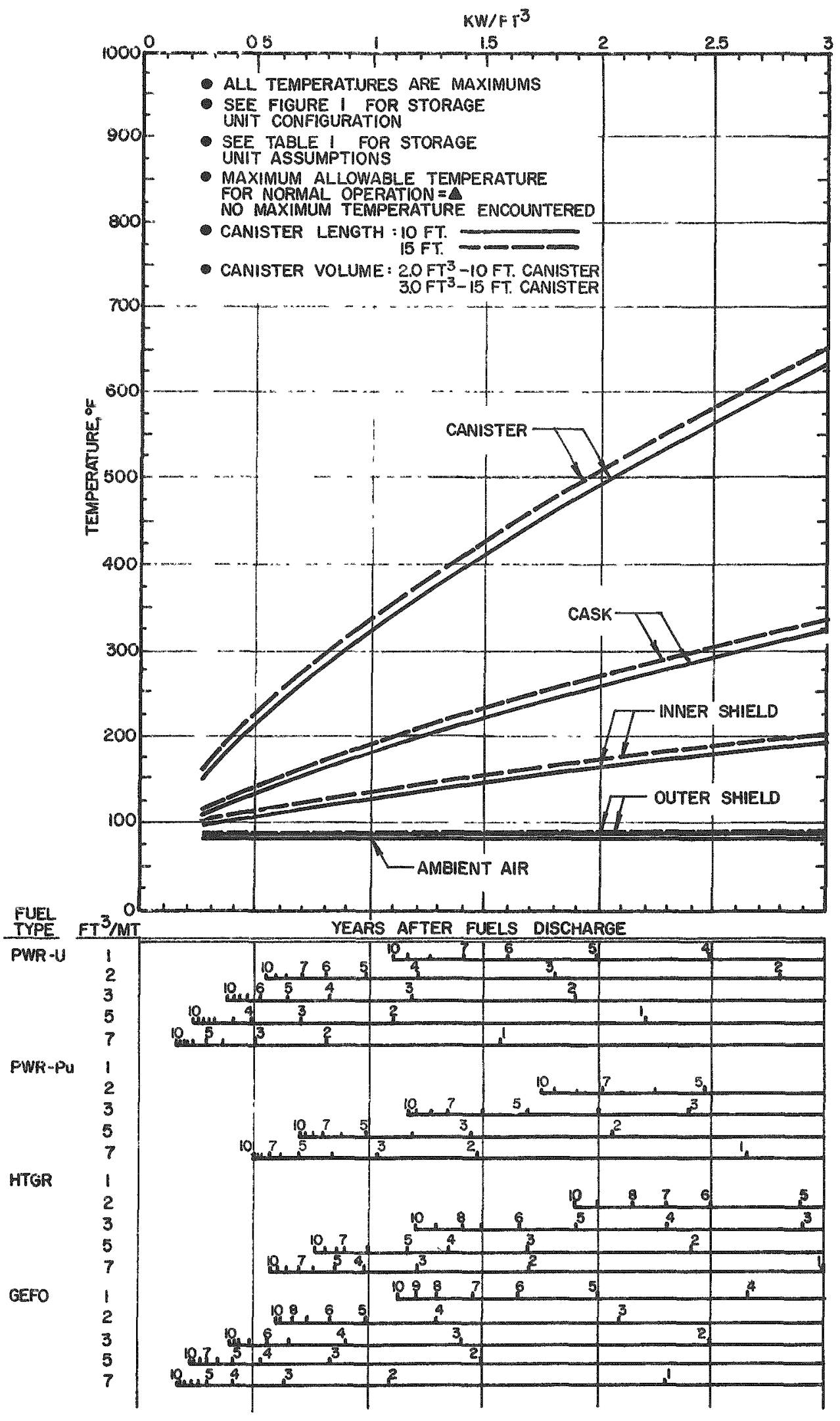

FIGURE B-I

STORAGE UNIT TEMPERATURES

SEALED STORAGE CASK CONCEPT

NORMAL OPERATION

CANISTER DIAMETER $=6 \mathbb{N}$. 


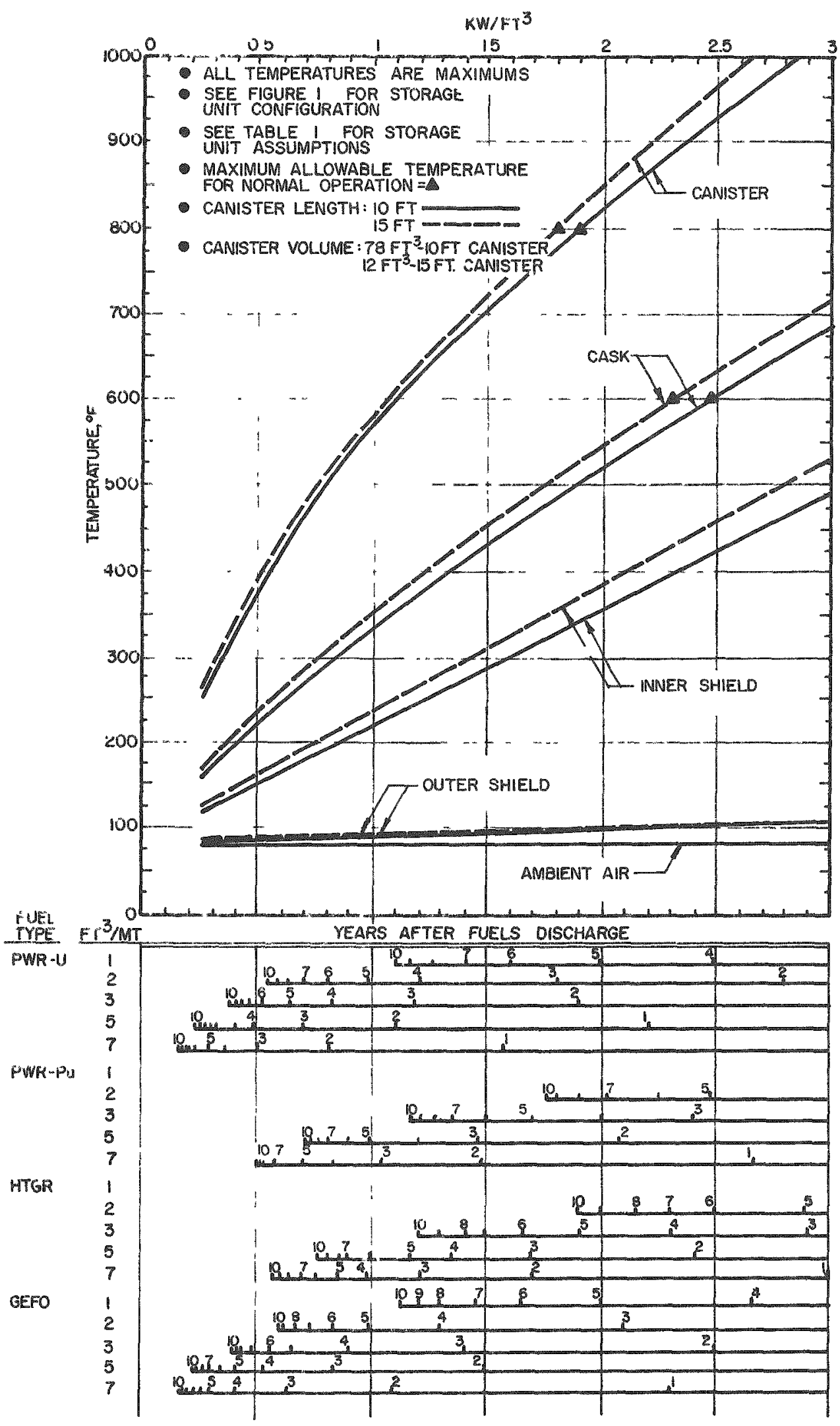

FIGURE B-2

STORAGE UNIT TEMPERATURES

SEALED STORAGE CASK CONCEPT

NORMAL OPERATION

CANISTER DIAMETER $=12 \mathrm{IN}$ 

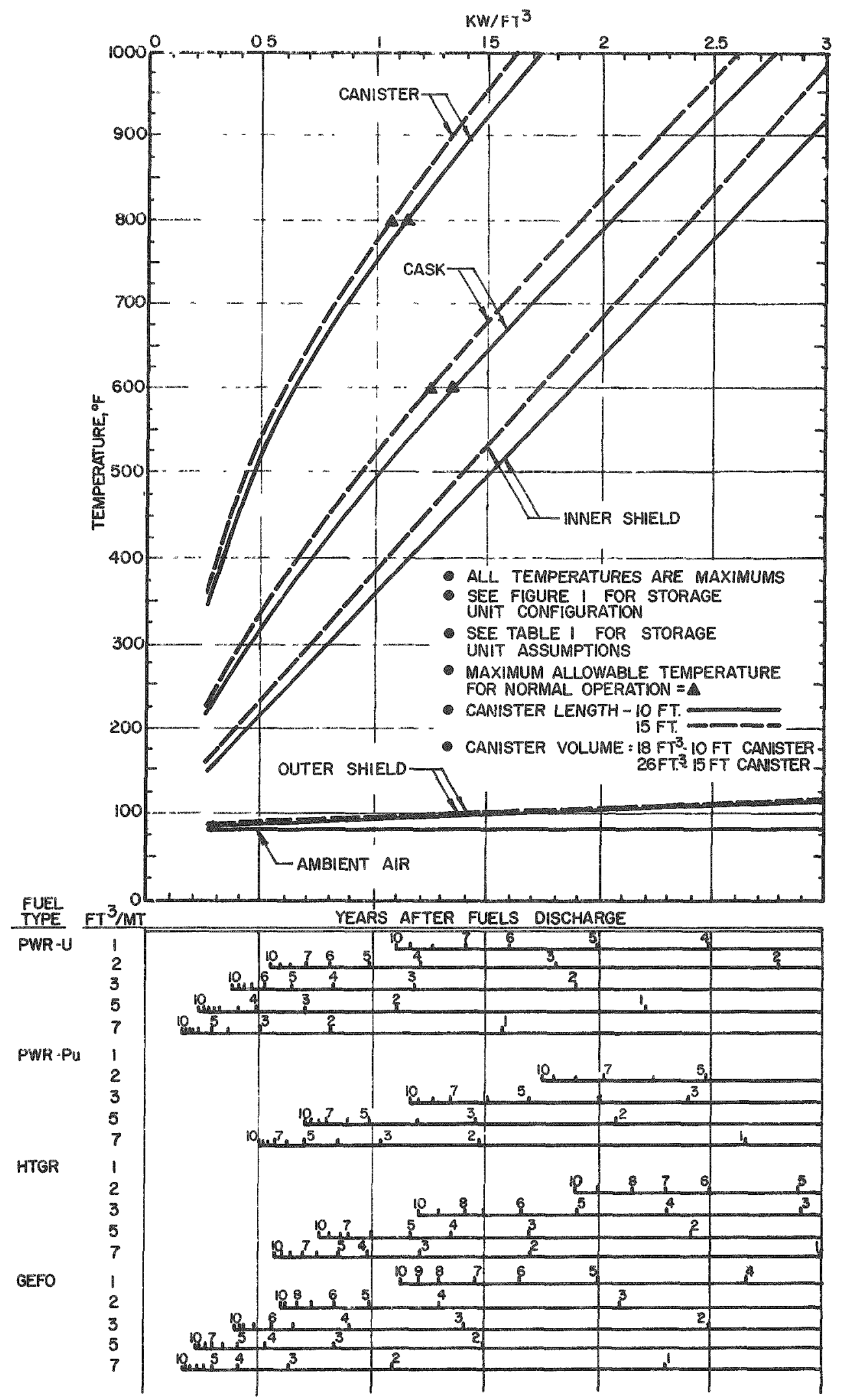

FIGURE B-3

STORAGE UNIT TEMPERATURES

SEALED STORAGE CASK CONCEPT

NORMAL OPERATION

CANISTER DIAMETER $=18 \mathrm{IN}$. 


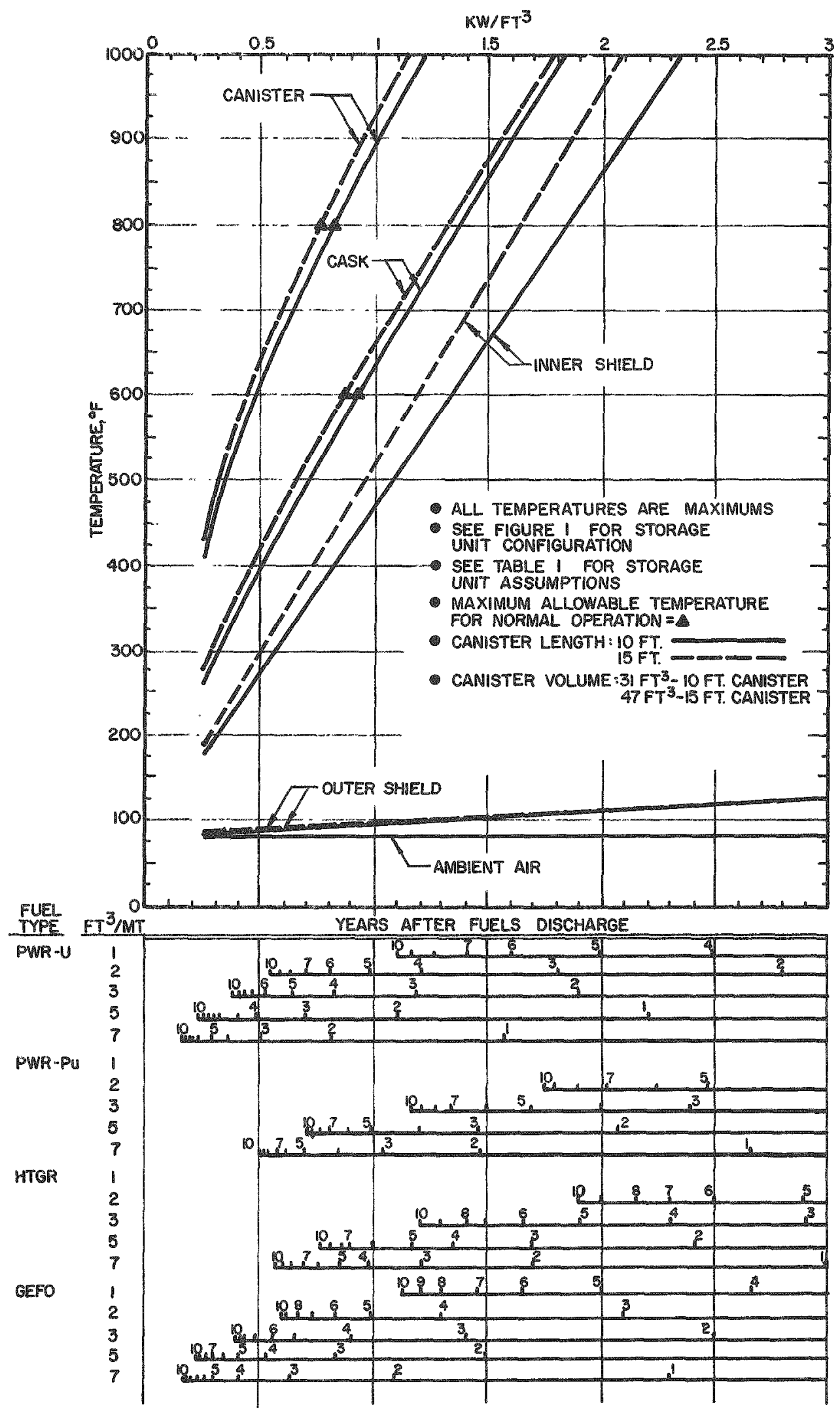

FIGURE $8-4$

STORAGE UNIT TEMPERATURES

SEALED STORAGE CASK CONCEPT

NORMAL OPERATION

CANISTER DIAMETER $=24 \mathrm{IN}$. 


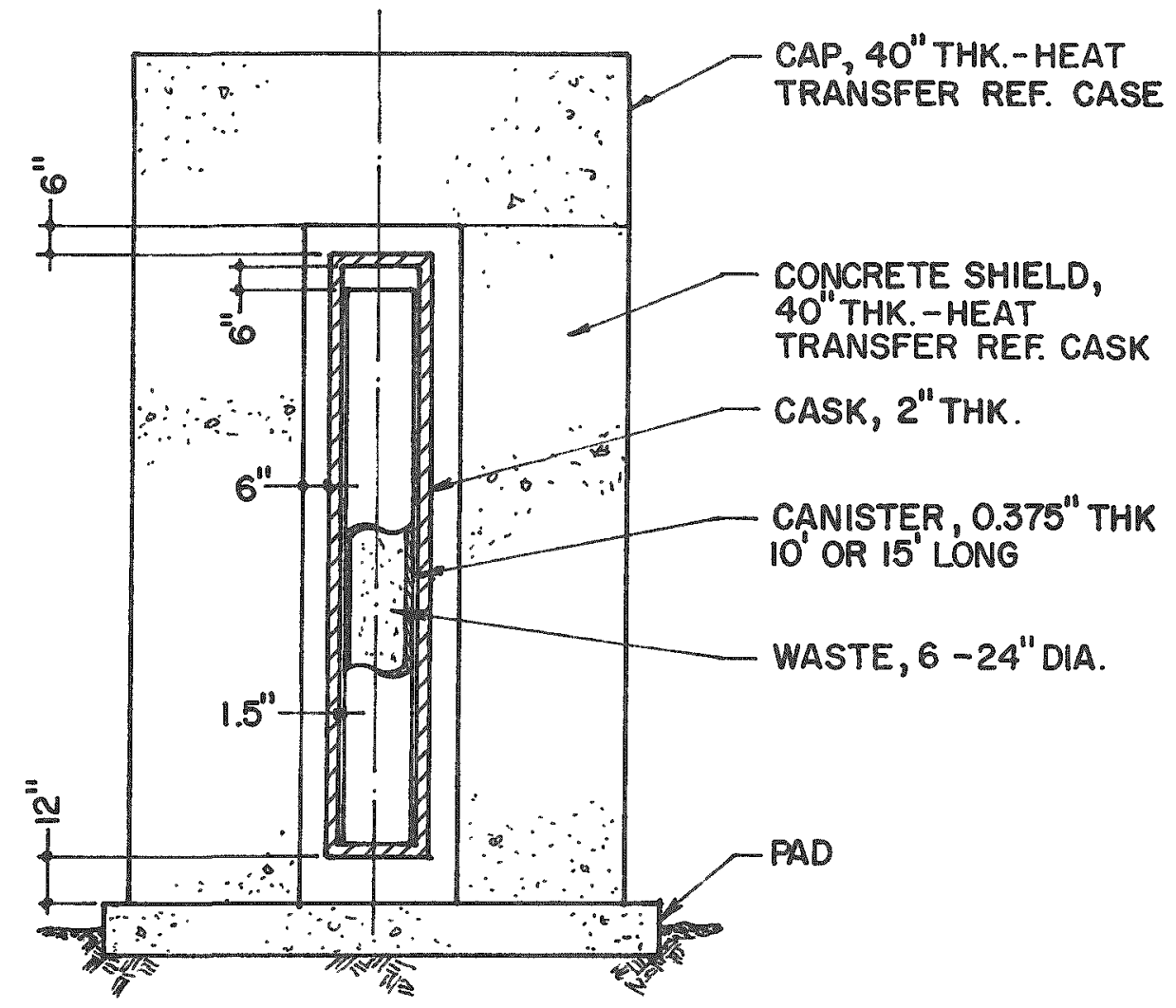

FIGURE B-5

SEALED STORAGE CASK CONCEPT

GENERIC WASTE STORAGE UNIT

AIR FLOW STOPPAGE 


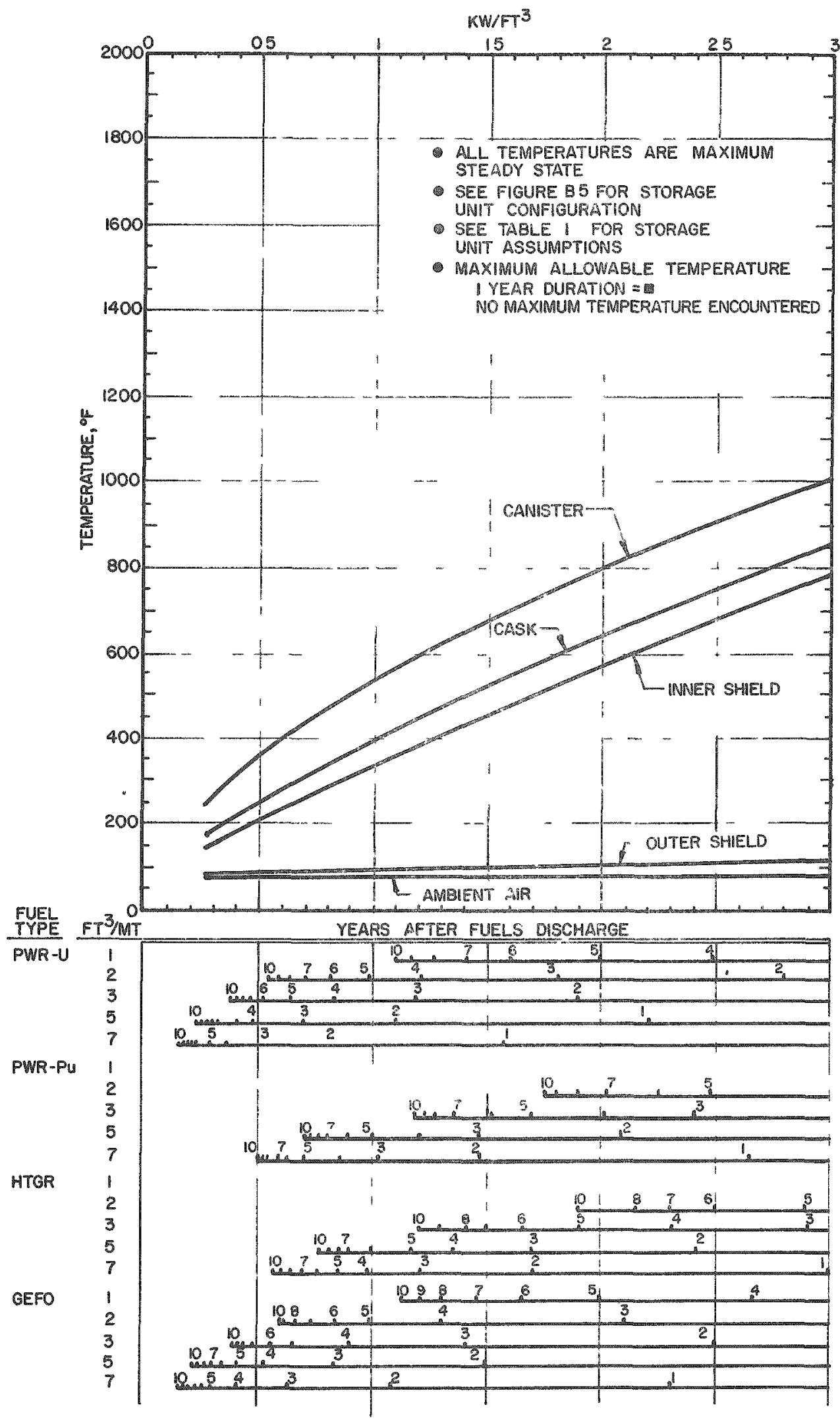

FIGURE B-6

STORAGE UNIT AIR FLOW STOPPAGE TEMPERATURES

SEALED STORAGE CASK CONCEPT

CANISTER DIAMETER $=6 \mathbb{N}$

CANISTER LENGTH $=10 \mathrm{FT}$.

CANISTER VOLUME $=2.0 \mathrm{FT}^{3}$ 


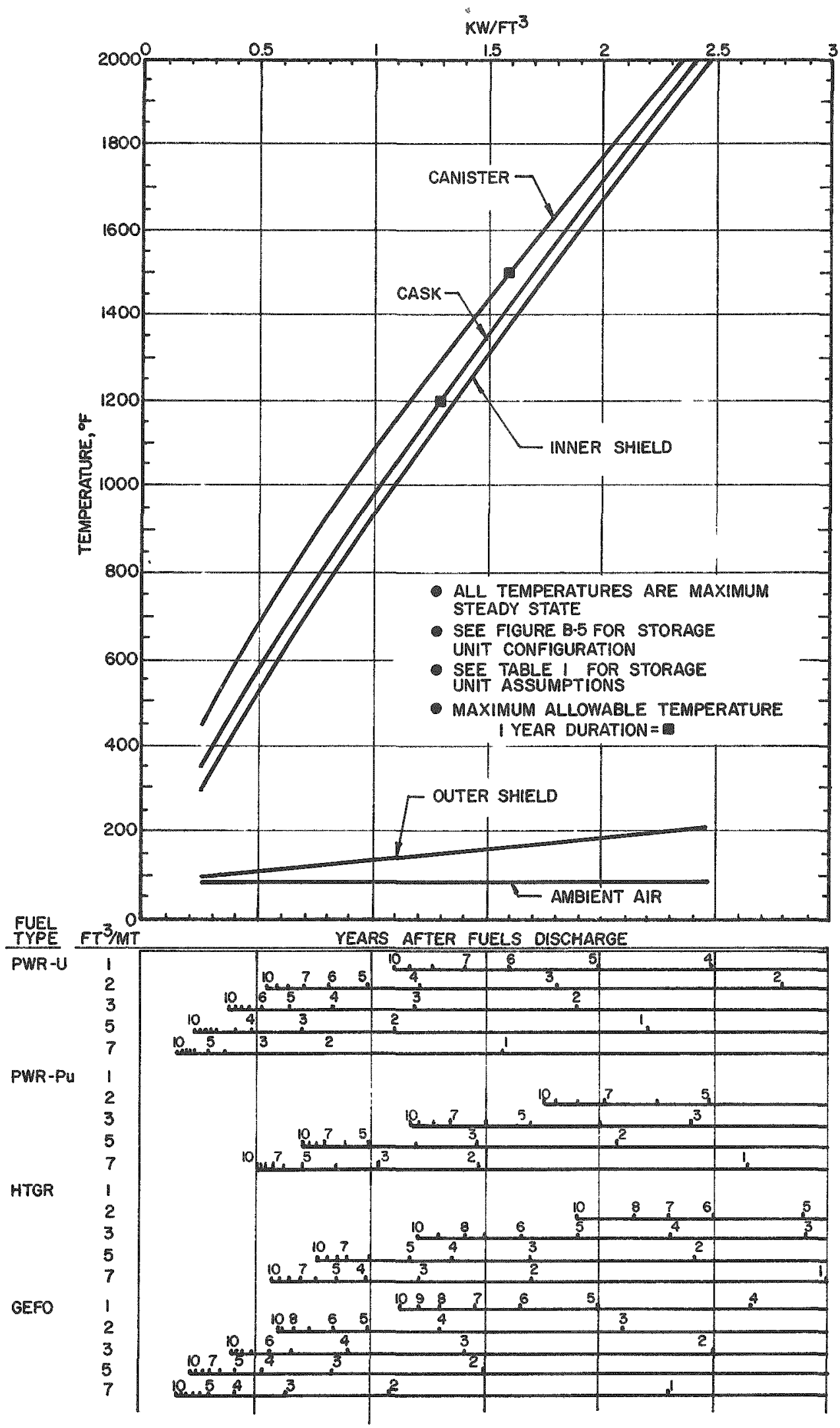

FIGURE B.7

STORAGE UNIT AIR FLOW STOPPAGE TEMPERATURES

SEALED STORAGE CASK CONCEPT

CANISTER DIAMETER $=12 \mathrm{IN}$.

CANISTER LENGTH = IO FT.

CANISTER VOLUME $=7.8 \mathrm{FT}^{3}$ 

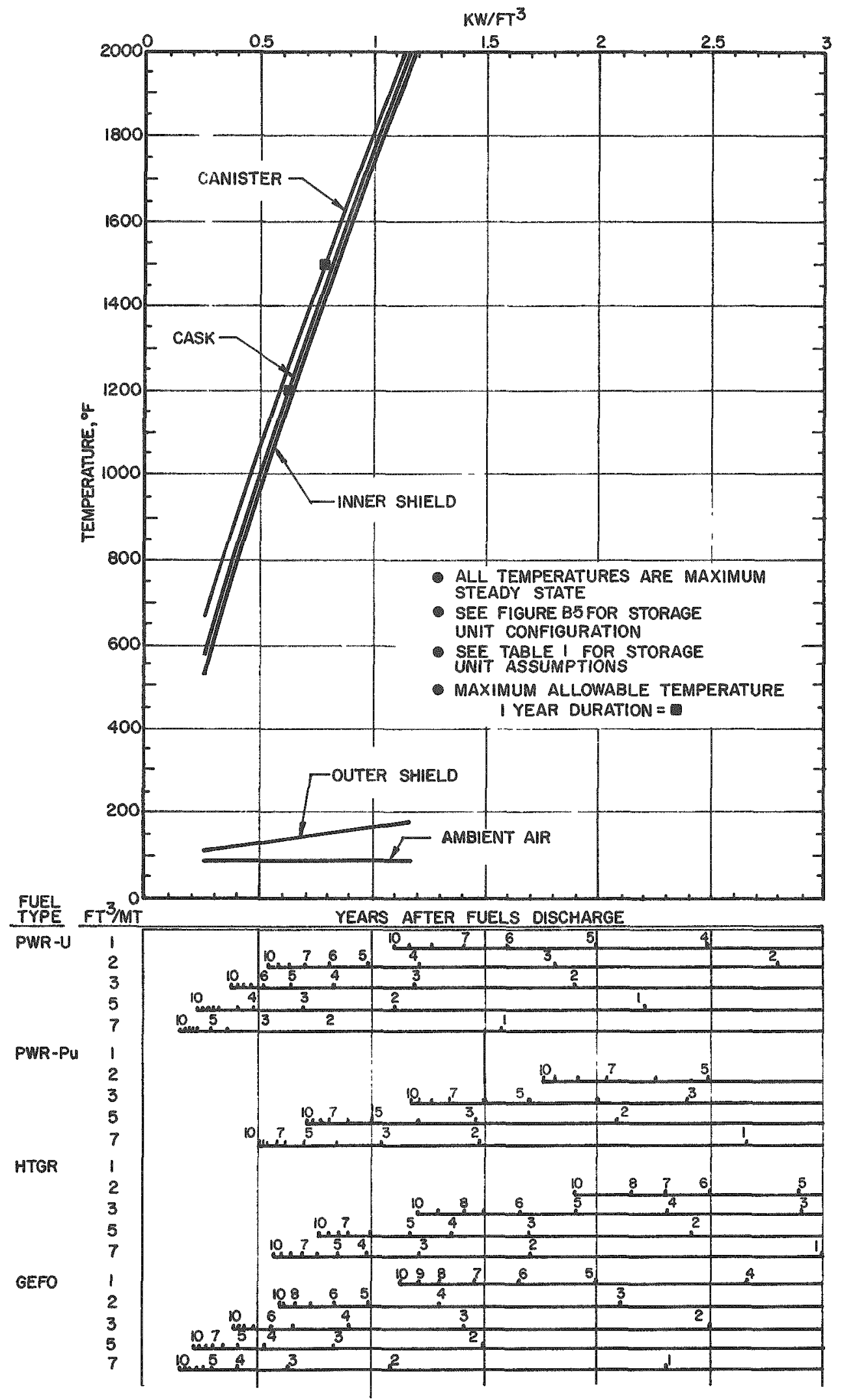

FIGURE B-8

STORAGE UNIT AIR FLOW STOPPAGE TEMPERATURES SEALED STORAGE CASK CONCEPT 


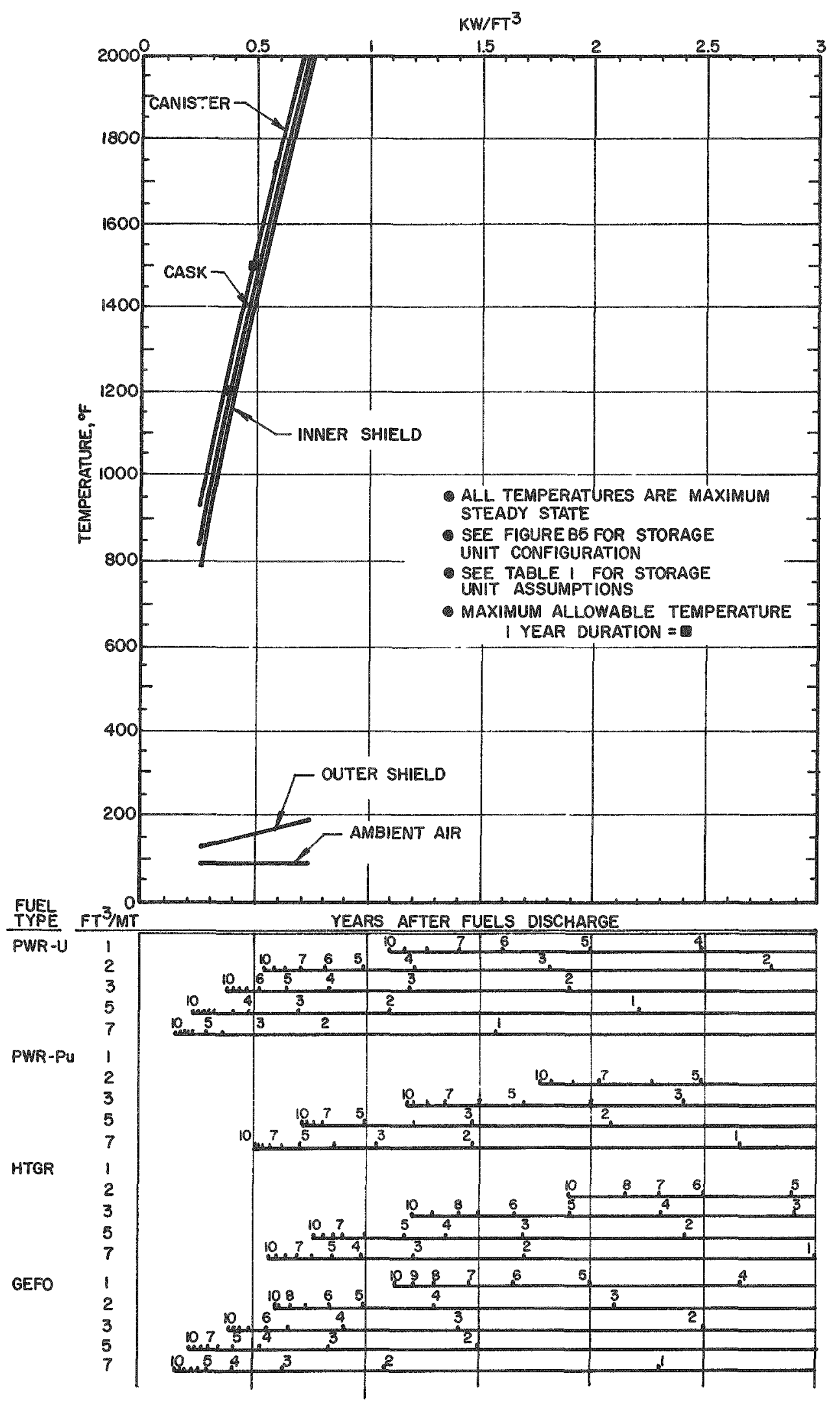

FIGURE B-9

STORAGE UNIT AIR FLOW STOPPAGE TEMPERATURES

SEALED STORAGE CASK CONCEPT

CANISTER DIAMETER $=24 \mathrm{IN}$.

CANISTER LENGTH $=10 \mathrm{FT}$.

CANISTER VOLUME : $31 \mathrm{FT}^{3}$ 

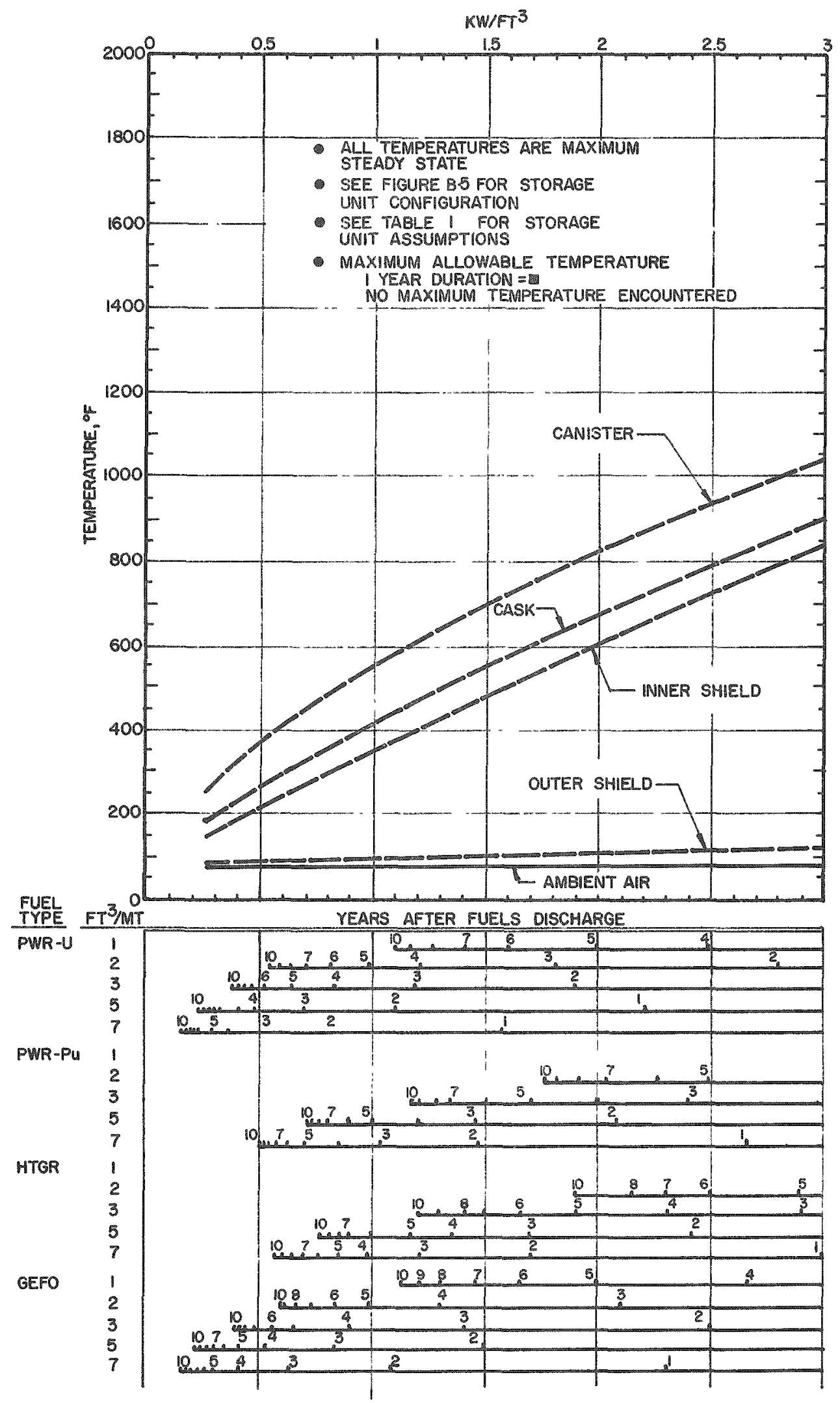

FIGURE B-10

STORAGE UNIT AIR FLOW STOPPAGE TEMPERATURES SEALED STORAGE CASK CONCEPT

CANISTER DIAMETER $=6$ IN .

CANISTER LENGTH $=15$ FT.

CANISTER VOLUME $=3.0 \mathrm{FT}^{3}$ 


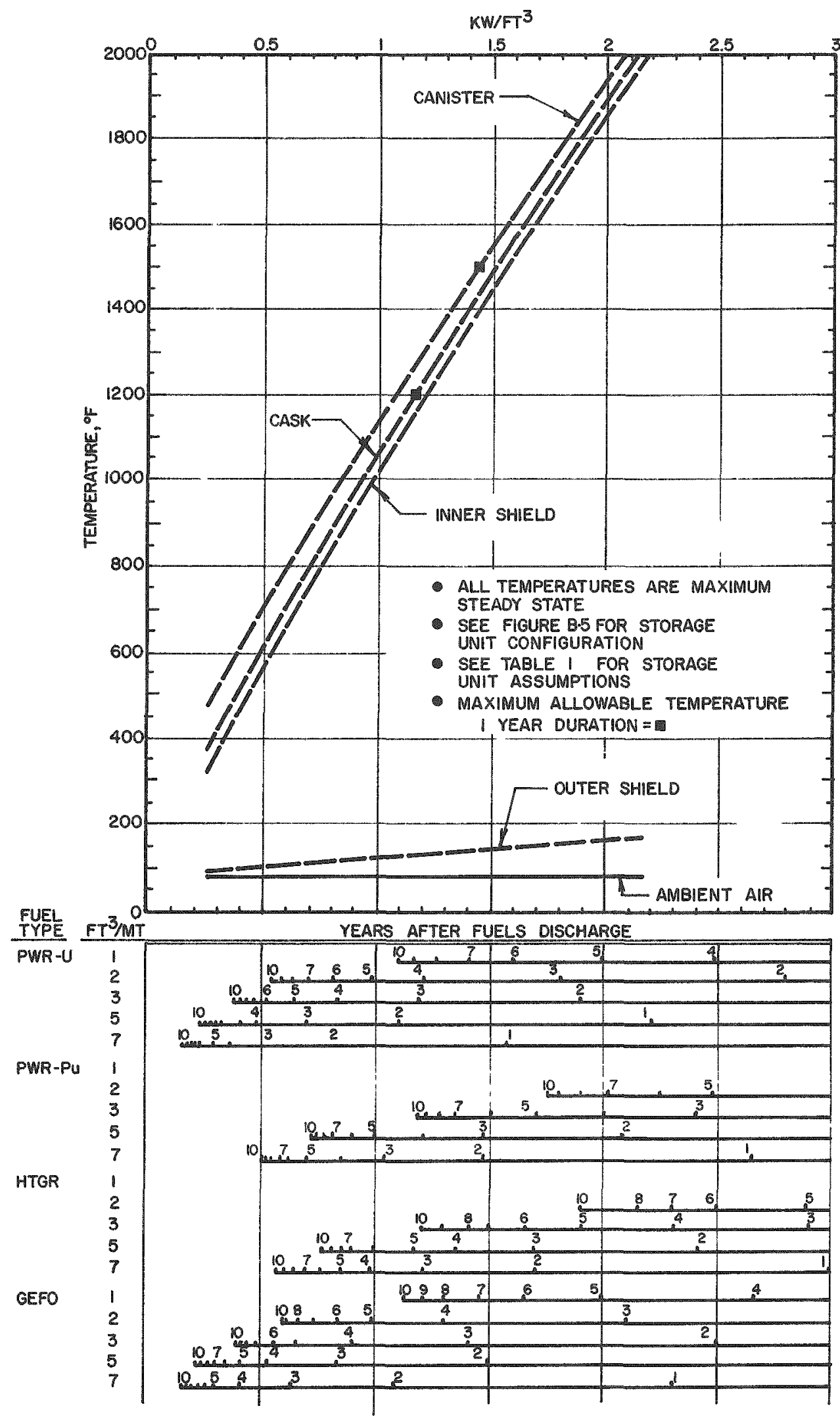

FIGURE B-II

STORAGE UNIT AIR FLOW STOPPAGE TEMPERATURES SEALED STORAGE CASK CONCEPT

CANISTER DIAMETER $=12 \mathbb{N}$.

CANISTER LENGTH $=15$ FT.

CANISTER VOLUME : 12 FT. 


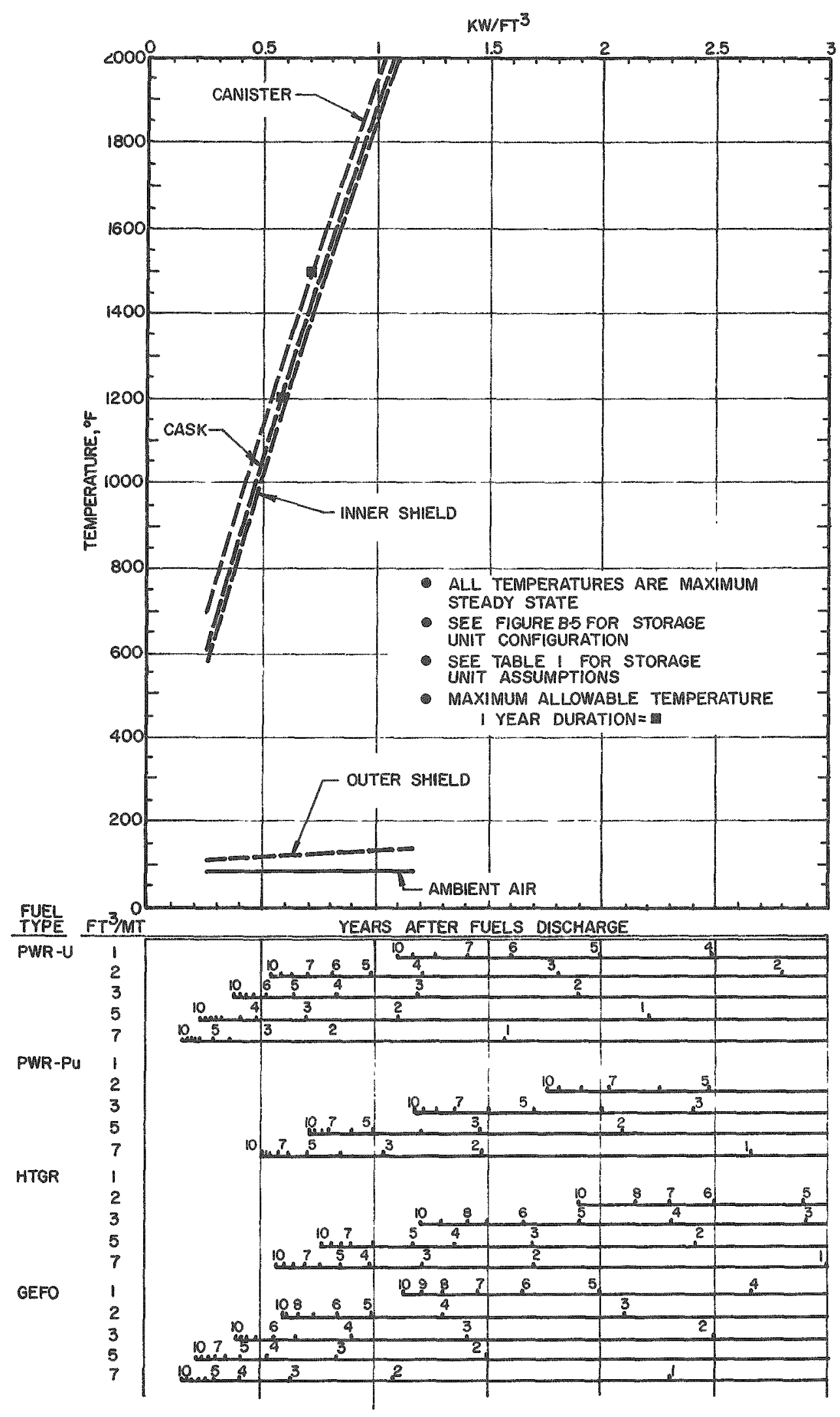

FIGURE B-12

STORAGE UNIT AIR FLOW STOPPAGE TEMPERATURES

SEALED STORAGE CASK CONCEPT

CANISTER DIAMETER = I8IN.

CANISTER LENGTH = $15 \mathrm{FT}$.

CANISTER VOLUME $=26 \mathrm{FT}^{3}$ 

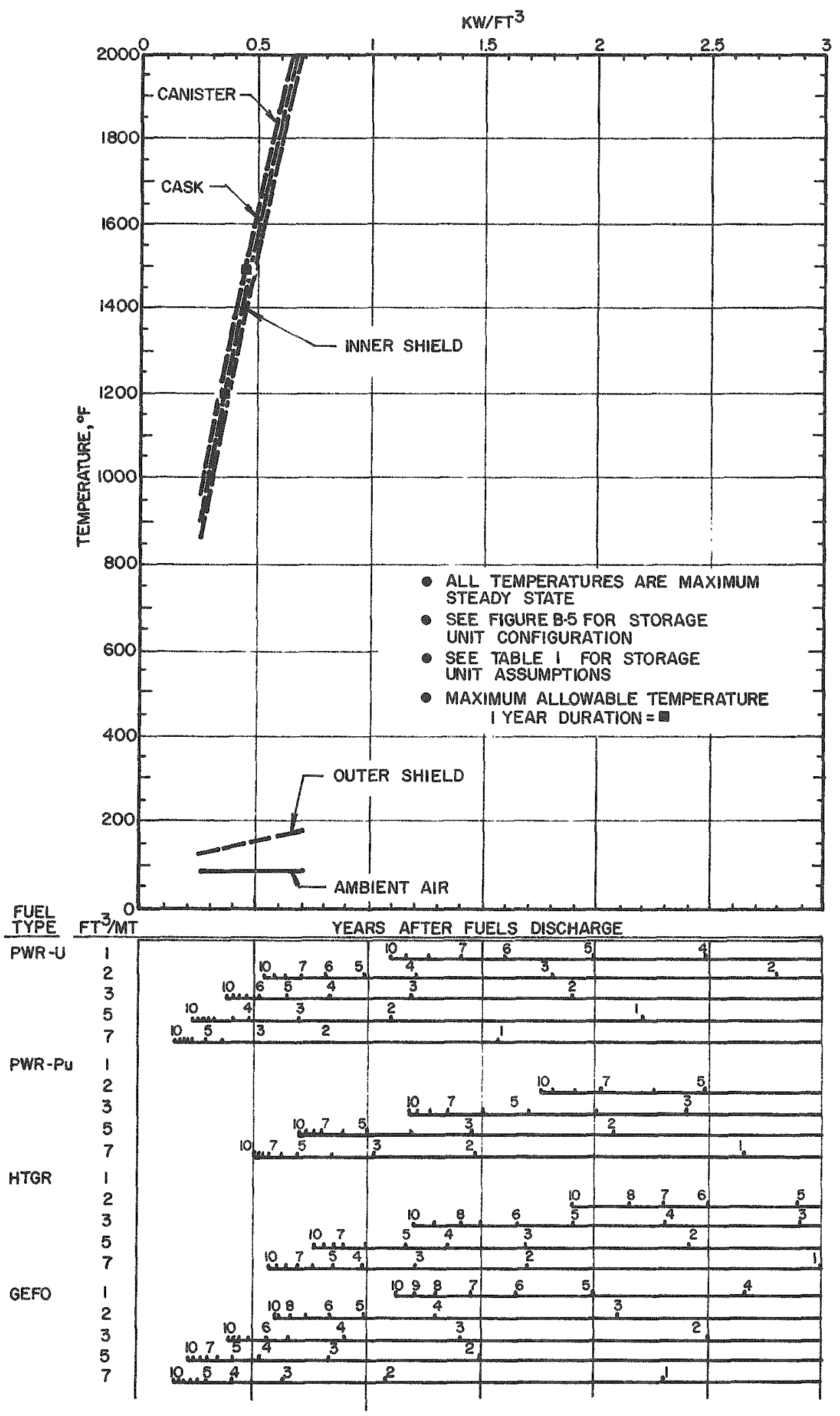

FIGURE B.13

STORAGE UNIT AIR FLOW STOPPAGE TEMPERATURES

SEALED STORAGE CASK CONCEPT

CANISTER DIAMETER $=24 \mathrm{IN}$.

CANISTER LENGTH $=15 \mathrm{FT}$.

CANISTER VOLUME $\approx 47 \mathrm{FT}^{3}$ 

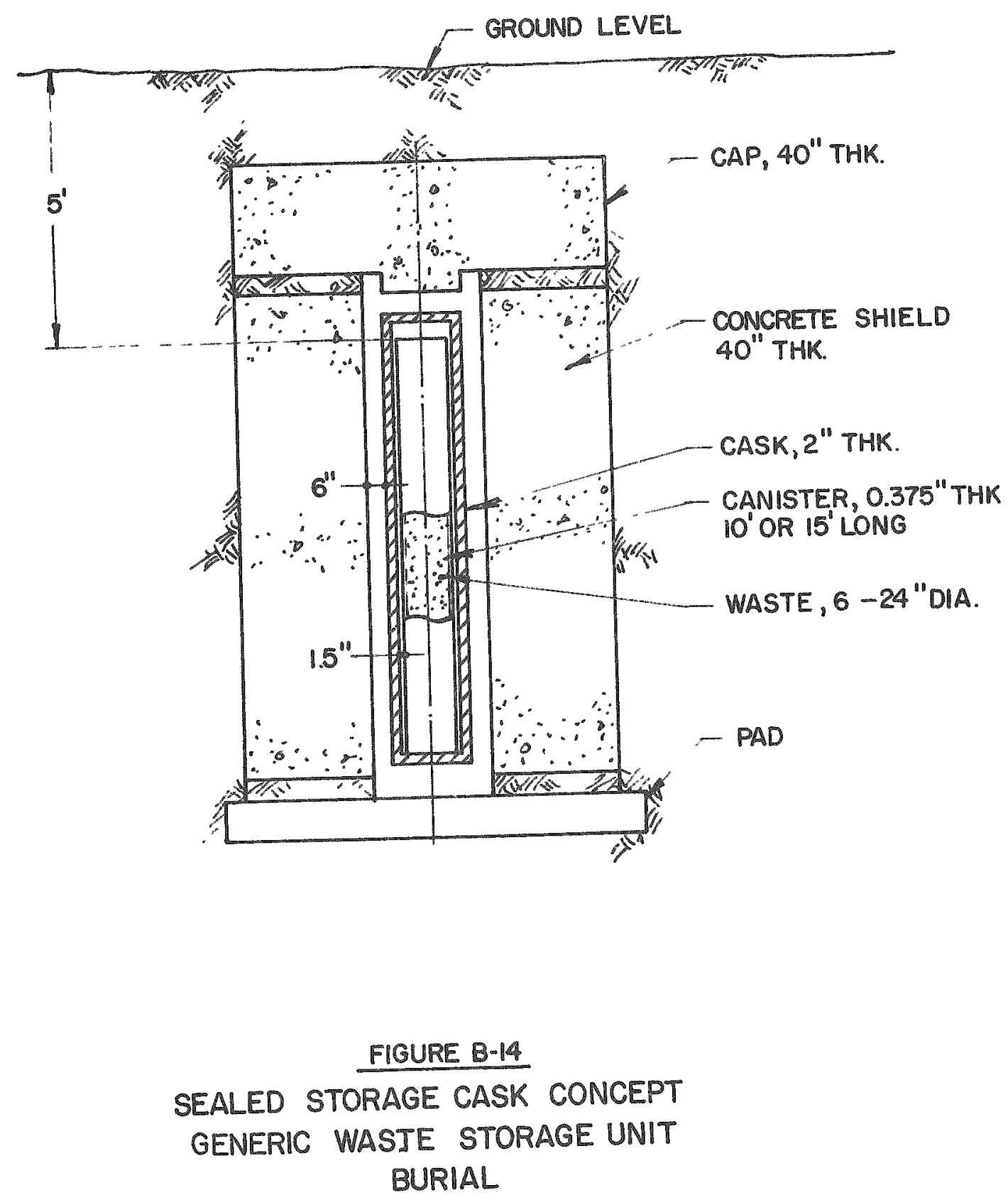


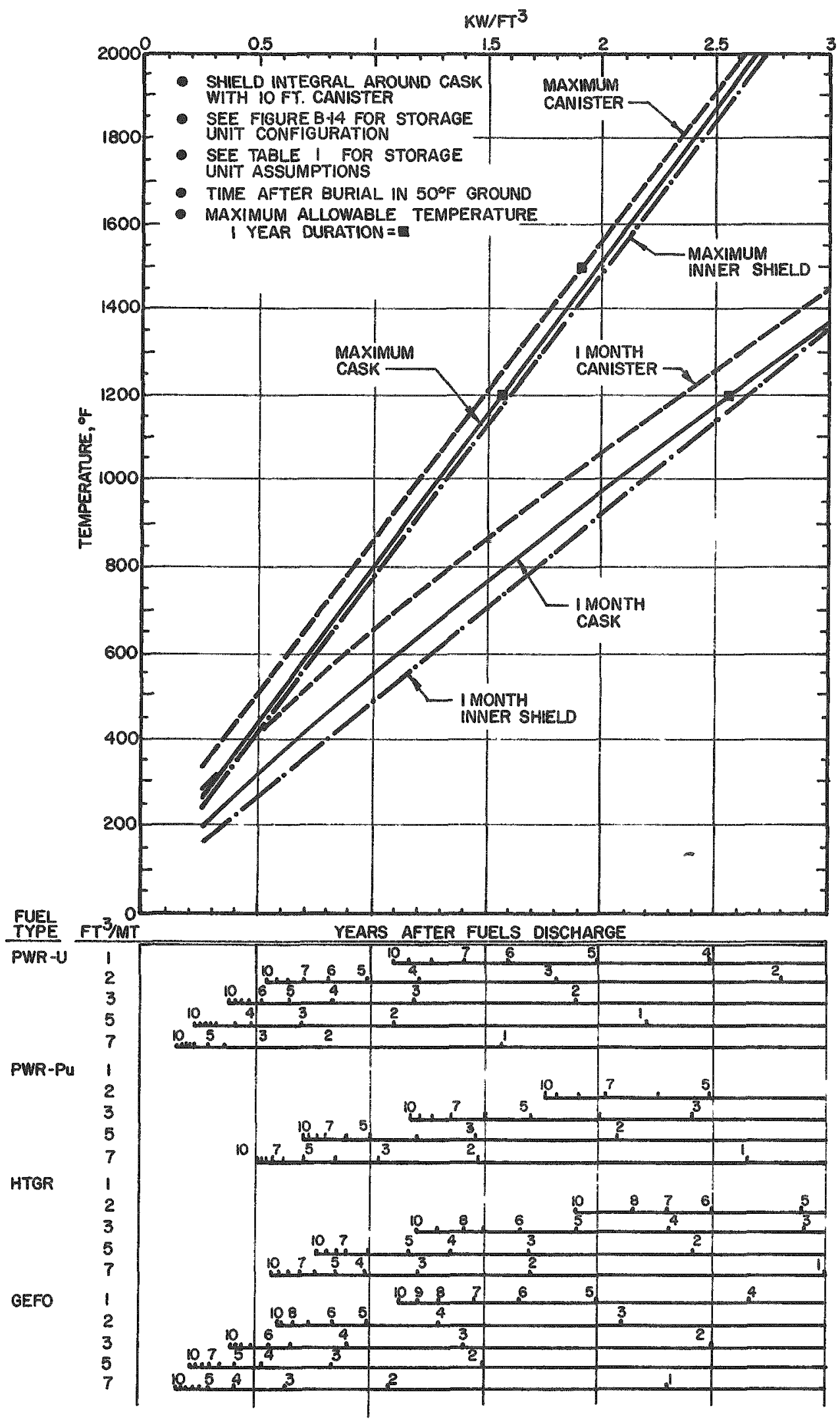

FIGURE B-15

STORAGE UNIT BURIAL TEMPERATURES

SEALED STORAGE CASK CONCEPT 


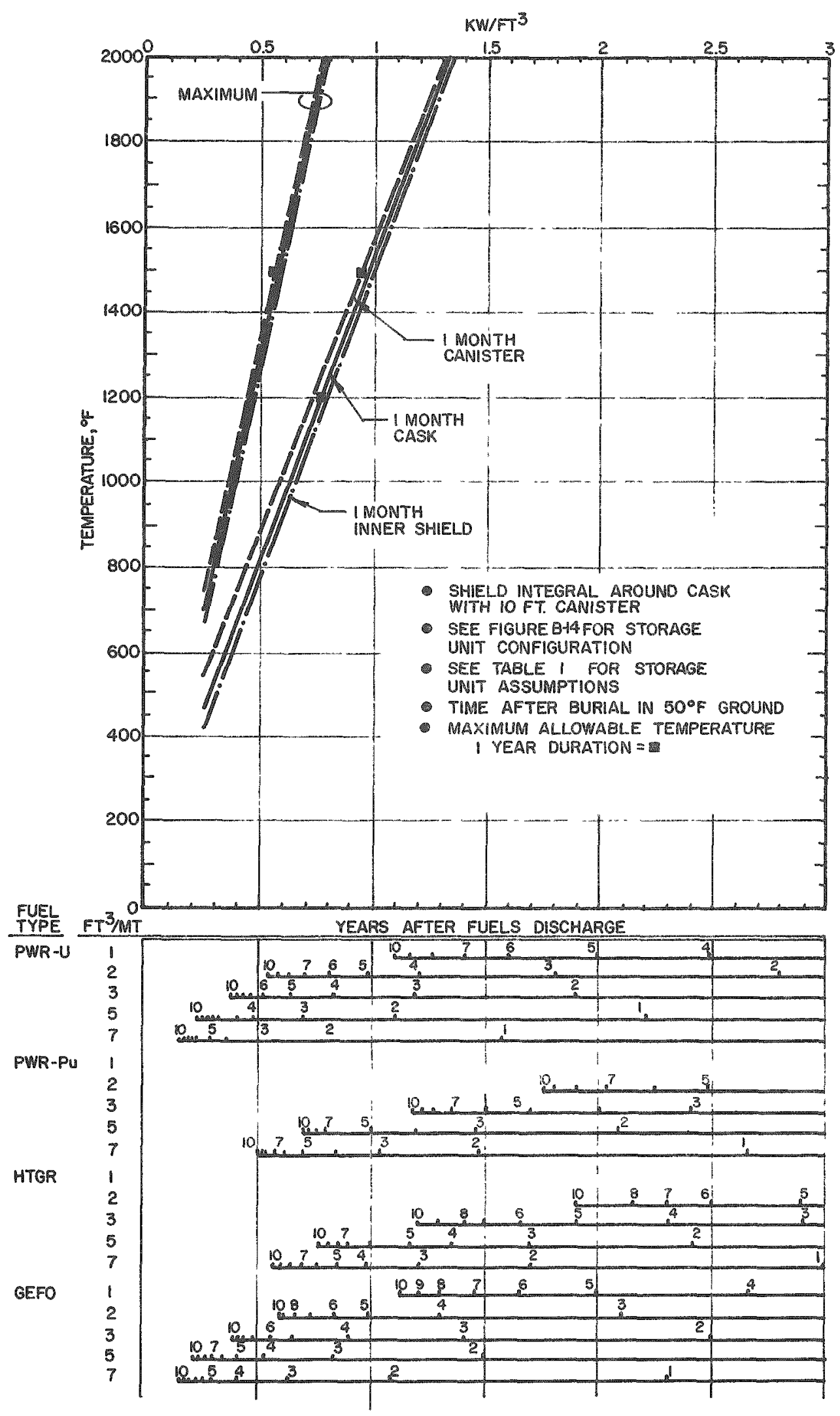

FIGURE 8-16

STORAGE UNIT BURIAL TEMPERATURES

SEALED STORAGE CASK CONCEPT

CANISTER DIAMETER $=12 \mathrm{~N}$.

CANISTER VOLUME $=7.8 \mathrm{FT}^{3}$ 

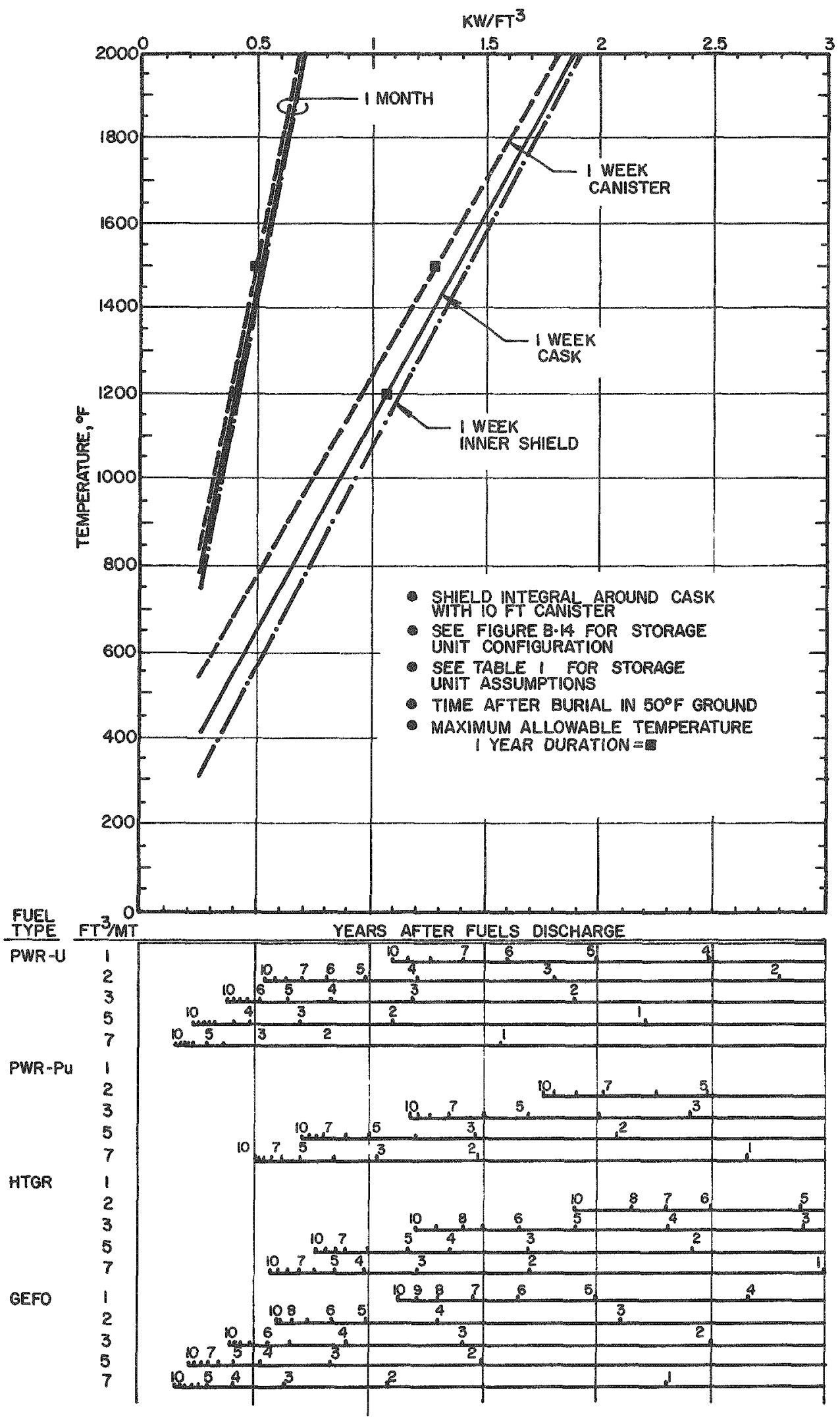

FIGURE B-17 


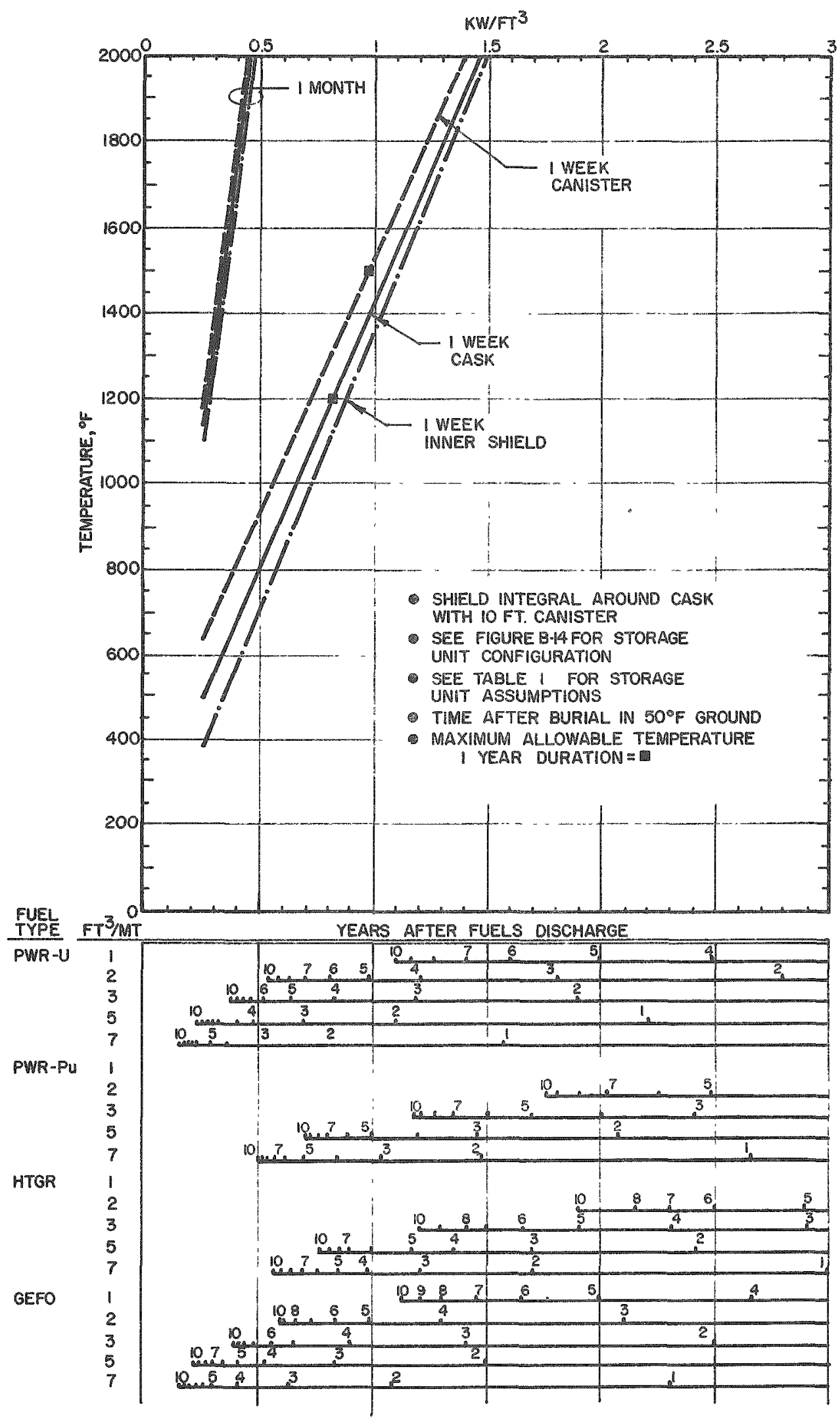

FIGURE $8-18$ 
DISTRIBUTION

Atomic Energy Commission

Richland Operations office

O. J. Elgert(2)

R. B. Goranson

D. J. Squires

Headquarters

D. G. Boyer

o. P. Gormley

A. F. Perge

F. K. Pittman

R. W. Ramsey, Jr.

Technical Information Center (2)

Kaiser Engineers

J. S. Ritchie(3)

Oak Ridge National Laboratory

J. O. Blomeke

Battelle Northwest

J. W. Bartlett

W. F. Bonner

H. C. Burkholder

J. R. Carrell

T. A. Golding

G. Jansen

J. L. MCEIroy

A. M. Platt

R. J. Schneider

M. G. Zimmerman

Allied General Nuclear Services

G. R. Bray (2)

E. R. Hager 


\section{General Electric Company}

R. G. Barns

Nuclear Fuels Services. Inc.

K. H. DuFrane

General Atomic Company

I. H. Brooks

D. T. Pence

Exson Nuclear Company

L. T. Lakey

G. I. Ritter

Atlantic Richfield Hanford Company

E. M. Bowers

W. M. Harty

A.R.F. Hawkins

D. E. Larson(20)

D. C. Nelson

H. P. Shaw

G. T. Stocking

M. J. Szulinski

D. D. Wodrich

Central File

ARHCO Document Services(2) 